\title{
The College Wealth Divide: Education and Inequality in America, 1956-2016
}

\author{
Alina K. Bartscher, Moritz Kuhn, and Moritz Schularick
}

\begin{abstract}
Using new long-run microdata, this article studies wealth and income trends of households with a college degree (college households) and without a college degree (noncollege households) in the United States since 1956. We document the emergence of a substantial college wealth premium since the 1980s, which is considerably larger than the college income premium. Over the past four decades, the wealth of college households has tripled. By contrast, the wealth of noncollege households has barely grown in real terms over the same period. Part of the rising wealth gap can be traced back to systematic portfolio differences between college and noncollege households that give rise to different exposures to asset price changes. Noncollege households have lower exposure to the equity market and have profited much less from the recent surge in the stock market. We also discuss the importance of financial literacy and business ownership for the increase in wealth inequality between college and noncollege households. (JEL I24, E21, D31)
\end{abstract}

Federal Reserve Bank of St. Louis Review, First Quarter 2020, 102(1), pp. 19-49.

https://doi.org/10.20955/r.102.19-49

\section{INTRODUCTION}

It is a well-documented fact that the college wage premium has increased substantially since the 1980s (see, e.g., Levy and Murnane,1992; Katz and Autor, 1999; and Goldin and Katz 2007). This trend can be traced back to differences in the growth of the demand for and the supply of college-educated workers that are driven by skill-biased technical change, sociodemographic factors, and institutional features (Card and Lemieux, 2001, and Fortin, 2006). Recent work has begun to analyze the relationship between college education and wealth inequality (Emmons, Kent, and Ricketts, 2018, and Pfeffer, 2018) and demonstrates an increasing association between college education and wealth.

\footnotetext{
The authors thank Jesse Bricker, participants of the symposium "Is College Still Worth It? Looking Back and Looking Ahead" at the Federal Reserve Bank of St. Louis, and an anonymous referee for helpful comments and suggestions. Alina K. Bartscher is a Ph.D. candidate at the University of Bonn. Moritz Kuhn is a professor at the University of Bonn, a research affiliate at the Centre for Economic Policy Research, and a research fellow at the IZA Institute of Labor Economics. Moritz Schularick is a professor at the University of Bonn and a research fellow at the Centre for Economic Policy Research.

(C) 2020, Federal Reserve Bank of St. Louis. The views expressed in this article are those of the author(s) and do not necessarily reflect the views of the Federal Reserve System, the Board of Governors, or the regional Federal Reserve Banks. Articles may be reprinted, reproduced, published, distributed, displayed, and transmitted in their entirety if copyright notice, author name(s), and full citation are included. Abstracts, synopses, and other derivative works may be made only with prior written permission of the Federal Reserve Bank of St. Louis.
} 
In this article, we take a long-run perspective on college and noncollege income and wealth over almost the entire post-WWII period. We use a novel household-level dataset, the "SCF+", which combines the post-1983 Survey of Consumer Finances (SCF) with data from historical surveys going back to 1949 . To ensure consistent coding of education groups, our analysis starts in 1956. Kuhn, Schularick, and Steins (forthcoming) have harmonized the data across the historical survey waves. The combined data provide long-run household-level information on income, assets, debt, and demographics. The SCF+ closes an important gap, as high-quality microdata were not previously available over longer time horizons. For instance, the Panel Study of Income Dynamics (PSID), which is one of the most important sources of household-level wealth data in the United States, has included questions on family wealth only since 1984 (see Pfeffer et al., 2016).

Our analysis confirms a strong increase in the college income premium since the early 1980s. The average income of college households has increased by about 50 percent in real terms since then. However, the increase of the college income premium is dwarfed by that of the college wealth premium. The wealth of college households has increased by a factor of three between 1983 and 2016, while that of noncollege households has barely grown at all. A substantial part of the widening of the wealth gap between college and noncollege households is driven by strong wealth gains within the top 10 percent of the wealth distribution. Moreover, the share of noncollege households making it to the top 10 percent of the wealth distribution has declined over time. We also document that households with two college-educated spouses have enjoyed particularly large gains in wealth. However, this trend is not driven by assortative matching, but by the overall growth in college education. Consistent with previous findings of Eika, Mogstad, and Zafar (forthcoming), assortative mating appears to have decreased among college graduates over time.

An important question raised by our findings is why the ratio of college to noncollege wealth has grown so much more than the income gap. The workhorse economic models of wealth accumulation imply tight comovement of income and wealth differences, as income is the sole determinant of wealth. We demonstrate that college and noncollege households exhibit systematic differences not only in the size of their asset holdings, but also in the composition of their portfolios. College households own a higher share of stocks and mutual funds. As a consequence, college and noncollege households are differentially exposed to asset price changes. College households reap disproportionately high capital gains during stock market booms. Importantly, such capital gains are unrelated to income. This is consistent with the decoupling of the evolutions of the college income and college wealth premiums since the 1980s (see also Kuhn, Schularick, and Steins, forthcoming).. We also find some indication that business ownership matters for the increase in the college wealth premium, especially since the late 1990s. The fact that the college wealth premium is associated with equity holdings and business ownership may be related to higher levels of financial literacy and entrepreneurial skills among college households. We discuss the role of these factors and their potential to affect wealth via portfolio composition and differential returns.

While this article documents a sharply rising college wealth premium in recent decades, it is important to note that causality can run in both directions. College graduates may hold 
more wealth due to their higher educational attainment, but there is also evidence that it is easier to obtain college degrees when coming from a wealthy family. Wealthy families can afford more investment in their offsprings' educational careers. The cost of college has increased considerably since the 1980s, which constitutes an obstacle for children from poorer households (see, e.g., Haveman and Smeeding, 2006). Beyond providing a basis for inter vivos transfers, wealth may have an insurance function as a "safety net" (Pfeffer, 2018). In this sense, it can work as a "catalyzer," facilitating human capital investment in early life. This will typically lead to higher wealth, which may be augmented by gifts and bequests. The process can accumulate across generations, creating a succession of college-educated households with ever more wealth (Pfeffer and Killewald, 2018). $\stackrel{2}{ }$ Our SCF+ data consist of repeated cross sections and therefore remain silent on intergenerational wealth links. At the same time, the wealth information in the PSID is less detailed than that in the SCF+, and in particular the coverage of wealth at the top is not comprehensive (Pfeffer et al., 2016). New data sources are needed to address these questions.

The paper begins with a description of the data in Section 2. In Section 3, we present our empirical results. Section 4 focuses on the role of asset prices and business ownership in college wealth growth. Section 5 discusses potential transmission mechanisms, and Section 6 concludes.

\section{DATA}

Our analysis is based on a newly compiled resource for inequality research, the SCF+. The modern SCF is conducted every three years by the Board of Governors of the Federal Reserve System (see Bricker et al., 2017). It is one of the most widely used datasets for the study of distributional issues in the United States. The modern waves cover the period since 1983. However, a predecessor of the modern surveys was conducted at an annual frequency by the Survey Research Center of the University of Michigan from 1947 to 1971 and again in 1977. Based on the original codebooks, Kuhn, Schularick, and Steins (forthcoming) extract the historical data. They match and harmonize variables across the historic and modern waves to create rich microdata that allow study of the joint distribution of income and wealth, along with key demographic variables, over the period 1949-2016. Bartscher et al. (2019) use the data to examine the post-war U.S. household debt boom. Following these papers, we pool the annual historic waves over three-year windows.

Missing data in the old waves were inferred by using multiple imputation methods such as predictive mean matching (cf. Schenker and Taylor, 1996), and historical data are reweighted to account for nonresponses at the top of the income and wealth distributions. These adjustments are described in detail in Kuhn, Schularick, and Steins (forthcoming). To assure representativeness along socio-demographic dimensions, the data were reweighted to match demographic targets from the U.S. Current Population Survey (CPS) and decennial census. Specifically, the data were post-stratified to match the age structure of the population, the share of households with a Black household head, the share of households whose head has at least obtained some college education, and the homeownership rate. ${ }^{3}$ For the new waves, the 
survey weights and data are the ones provided on the website of the Board of Governors of the Federal Reserve System. The only amendment we made is to post-stratify the original 1983 weights to match the CPS homeownership rate. This is done for better consistency with the modern waves, which match the homeownership rate closely.

The key advantage of the dataset is that it combines rich information on economic and financial data with key socio-demographic variables. Kuhn, Schularick, and Steins (forthcoming) exploit this feature of the data to study another key stratifying dimension of inequality, namely race. They find that income and wealth gaps between Black and White households have hardly narrowed since the pre-civil rights era: The median Black household only had about half the income and one-tenth of the wealth of the median White household. By 2016, the income ratio of the median Black to median White household had increased by only 10 percentage points and the wealth gap had remained almost unchanged. We will abstain from a joint analysis of education and race due to low numbers of observations when slicing the data along both dimensions in the early years.

Total household income in the SCF+ data includes income from wages and salaries, professional practice and self-employment, rental income, interest, dividends, business and farm income, as well as transfer payments. Assets comprise liquid assets (certificates of deposit and checking, saving, call, and money market accounts), housing and other real estate (net of debt), bonds, stocks, mutual funds, corporate and noncorporate equity, and definedcontribution retirement accounts. Total debt sums housing debt on primary residences, car loans, education loans, loans for consumer durables, other nonhousing debt, and credit card debt. Wealth is computed as total assets net of total debt. All monetary variables were transformed to 2016 dollars using the U.S. consumer price index (CPI) for all urban consumers from the Macrohistory Database (Jordà, Schularick, and Taylor, 2017). This is also the source for the stock price data used in Section 4.

Figure 1 compares the share of households headed by a college graduate in the SCF + with data from the CPS, which are available since 1962. For the earlier period, we rely on linearly interpolated data from the decennial census. Throughout the article, college households are households whose head has obtained at least a bachelor's degree. Householders with "some college" are included in the group of noncollege households. ${ }^{4}$ The distinction between households with some college versus a college degree was not made in the earliest surveys, and there are notable differences in the portfolios and incomes of these groups (Table 2). Therefore, we decided to discard the first two three-year windows and let our sample begin with the 1956 window (1954-56).

While a close match to targeted census shares is a good test of the reweighting procedure, it does not necessarily imply that the aggregated microdata match macroeconomic variables. Yet Kuhn, Schularick, and Steins (forthcoming) demonstrate that the SCF+ data closely match aggregate trends in income, wealth, housing, financial and nonfinancial assets, and housing and nonhousing debt. In addition, they demonstrate that the data exhibit a close fit to top income shares from Piketty and Saez (2003) using IRS tax data, and top wealth shares from Piketty and Saez (2003) using IRS data and the capitalization method. 


\section{Figure 1}

\section{Comparison to Census Data}

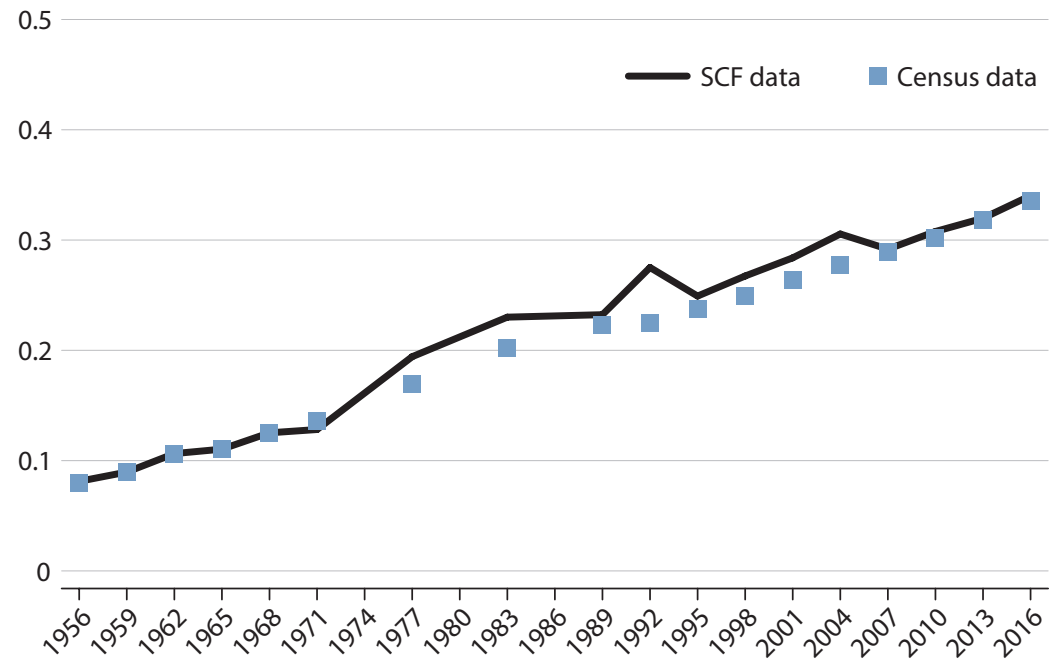

NOTE: The figure shows the share of households with a college-educated head in the SCF+ data compared with the shares obtained from the CPS for 1962-2016 and from the U.S. decennial censuses for 1950 and 1960. Intermediate data points were obtained by linear interpolation.

\section{SIX DECADES OF COLLEGE INCOME AND WEALTH PREMIA}

Going beyond previous research, the SCF+ data allow us to document income and wealth differences between college and noncollege households over the long run. As discussed above, much of the previous literature has focused on wage differences between college and noncollege individuals. Instead of looking at wages at the individual level, we consider total income and wealth at the household level, with a particular focus on the college wealth premium, the ratio of college to noncollege wealth.

\subsection{Income and Wealth Growth}

Figure 2 shows the development of average household income and wealth for college and noncollege households. The two groups evolved similarly until the 1970s and diverged thereafter. In Figure 2, we normalize the data to 1971 to track the divergence since the 1970s. Figure 2A reveals that income has grown at, by and large, similar rates for both groups until the 1970s. Thereafter, the real income of noncollege households stagnated, while the real income of college households has risen by around 50 percent. In other words, our data confirm a secular rise in the college income premium.

The differential growth of college and noncollege income is considerable, but it is dwarfed by the discrepancy in wealth. As with income, wealth evolved similarly for both groups until the 1970s and stagnated for noncollege households thereafter. The only exception is the period prior to the Financial Crisis of 2007-09, when noncollege households increased their wealth 


\section{Bartscher, Kuhn, Schularick}

\section{Figure 2}

\section{Wealth and Income Levels}
A. Income
B. Wealth

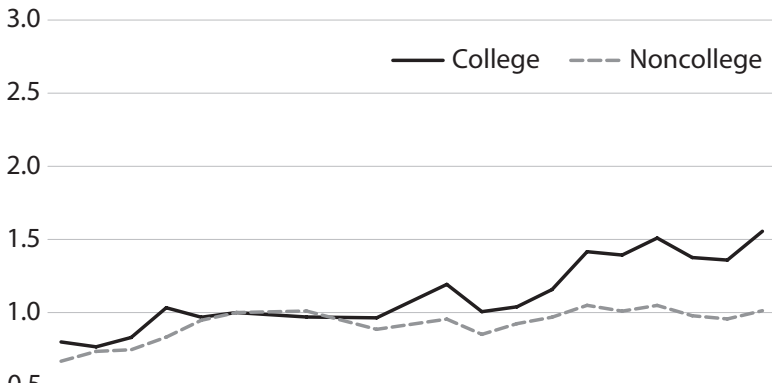

0.5
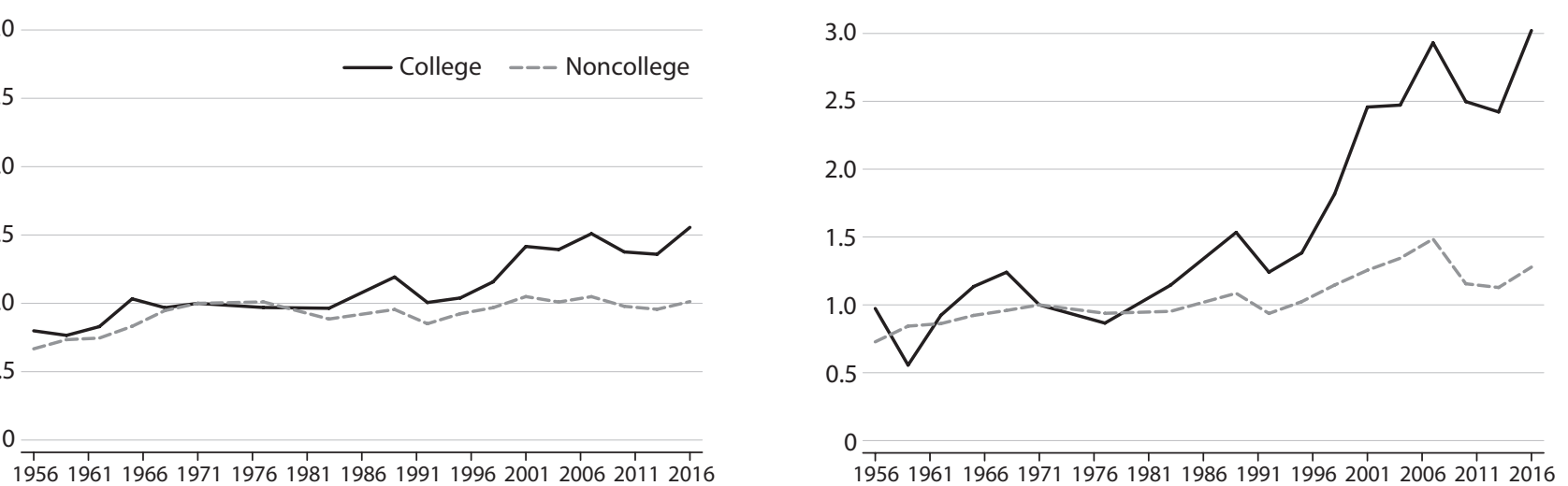

1956196119661971197619811986199119962001200620112016

NOTE: The figure shows the average income and average wealth, respectively, of college and noncollege households normalized by each group's level in 1971.

Figure 3

Wealth-to-Income Ratios

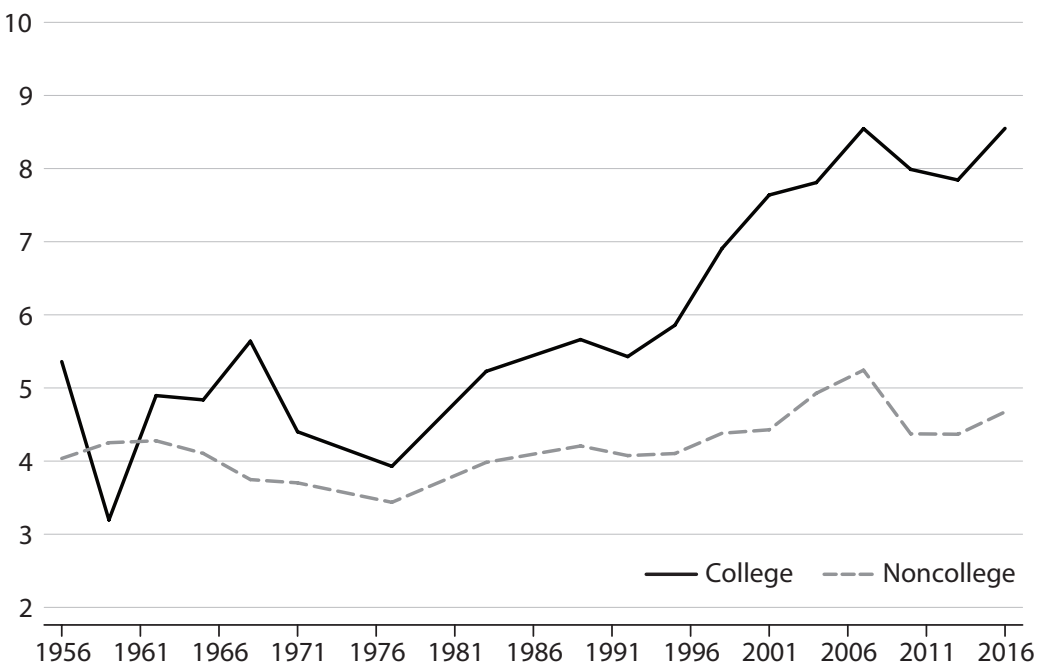

NOTE: The figure shows the ratios of average net wealth to average income of college and noncollege households, respectively. 
to around 1.5 times its 1971 level. Consistent with the results of Kuhn, Schularick, and Steins (forthcoming), this was mainly due to the short-lived effects of the house price boom in the 2000s. As we document below, housing constitutes a particularly large share of total wealth for noncollege households (see Figure 12). While noncollege households were treading water in terms of wealth, college households have increased their net worth by a factor of three compared with 1971. As average wealth has increased by more than average income for both college and noncollege households, wealth-to-income ratios have expanded as well. $\underline{5}$ However, the increase has been much larger for college households due to their massive surge in wealth. Their wealth-to-income ratio has roughly doubled, from around 4.4 in 1971 to 8.5 in 2016, as shown in Figure 3. The corresponding growth for noncollege households was only 26 percent, from around 3.7 to 4.7. Figure A2 in the appendix shows that the gap between the two groups is somewhat reduced when excluding pension wealth. Yet the difference still remains substantial: While college households would still have experienced an increase in their average wealth-to-income ratio by a factor of approximately 1.6 (from 4.4 to 7.1 ) without pensions, noncollege households would not have experienced any increase in wealth relative to income apart from the house-price-boom period prior to 2007.

\subsection{Decomposing Wealth Growth}

In the next step, we explore wealth growth for three different wealth groups. Within each of these wealth groups, we distinguish between college and noncollege households. In the middle group, which we define as the 50th to 90th percentiles of the wealth distribution, college and noncollege wealth has to comove closely by construction, as it is limited both from below and above. What can change for this group is the shares of college and noncollege households who belong to the group. Figure 4 shows wealth growth for all three wealth groups, stratified by education. It reveals that the widening of the college wealth gap has been pronounced within the top 10 percent of the aggregate wealth distribution, whereas college and noncollege households have evolved similarly within the bottom 50 percent and the middle $50-90$ percent. $\underline{6}$ As Kuhn, Schularick, and Steins (forthcoming) point out, households in the top 10 percent of the aggregate wealth distribution are more heavily invested in equity and business wealth. We will discuss the role of these factors in more detail in Sections 4 and 5. The graphs for the different parts of the aggregate wealth distribution in Figure 5 relate to Figure 2B via the following decomposition:

$$
\frac{\bar{W}_{e, t}}{\bar{W}_{e, 71}}=\frac{\sum_{i=1}^{3} s_{e, i, t} \bar{W}_{e, i, t}}{\bar{W}_{e, 71}}=\sum_{i=1}^{3} s_{e, i, t} \frac{\bar{W}_{e, i, 71}}{\bar{W}_{e, 71}} \frac{\bar{W}_{e, i, t}}{\bar{W}_{e, i, 71}} \quad e=c, n c .
$$

$\bar{W}_{e, t}$ denotes average wealth of education group $e \in\{c, n c\}$ at time $t$, where $c$ means college and $n c$ means noncollege. The index $i \in\{1,2,3\}$ refers to the three groups of the aggregate wealth distribution, and $s_{e, i, t}$ is the share of households in education group $e$ and wealth group $i$ out of all households in education group $e$ at time $t$. Hence, the widening of the college wealth gap in Figure 2B depends on three factors: initial conditions in the base period, the development of the share $s_{e, i, t}$ over time, and the wealth growth in each education-wealth group depicted 


\section{Bartscher, Kuhn, Schularick}

\section{Figure 4}

\section{Wealth Growth Along the Wealth Distribution}

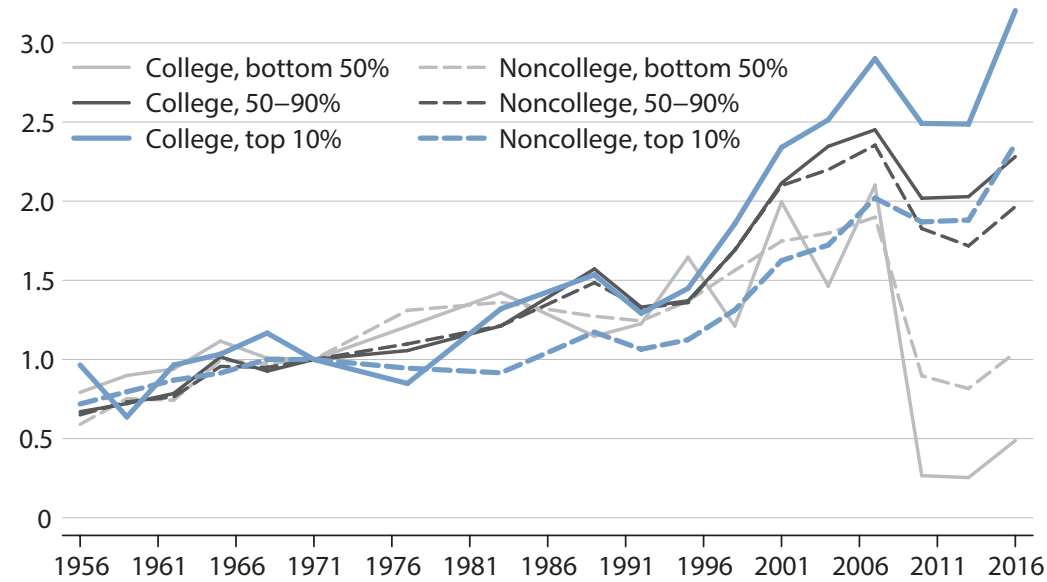

NOTE: The figure shows the average wealth growth of college and noncollege households in the bottom 50 percent, middle 50-90 percent, and top 10 percent of the aggregate wealth distribution over time, respectively, relative to 1971.

\section{Figure 5}

\section{Wealth Growth Counterfactuals}

\section{A. Counterfactuals: College}

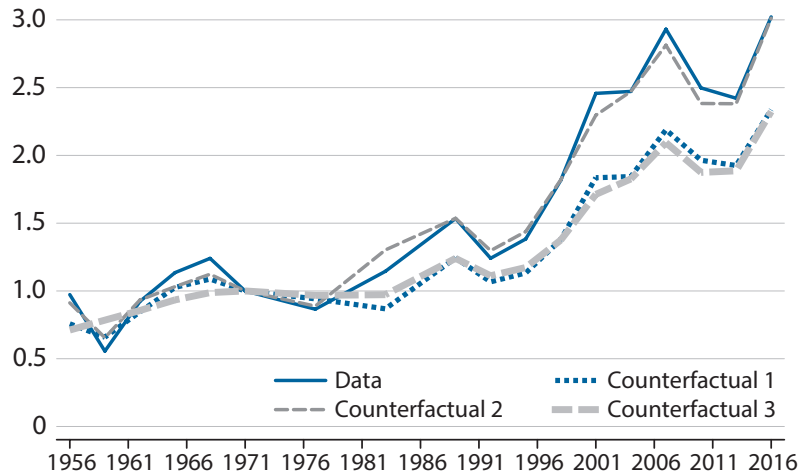

\section{B. Counterfactuals: Noncollege}

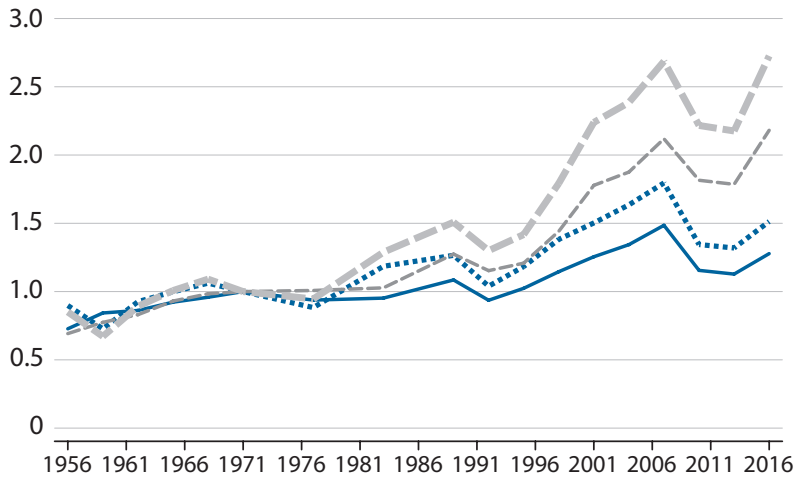

NOTE: Figure 5A shows three counterfactuals for college households. In Counterfactual 1, college households from the top 10 percent of the aggregate wealth distribution are assigned the average wealth growth of their noncollege counterparts, $\bar{W}_{n c, \text { top 10, }} / \bar{W}_{n c, \text { top 10,71. }}$. In Counterfactual 2, the share of college households in each wealth group $i$ is fixed at its 1971 level, $s_{c, i, 71}$. Counterfactual 3 combines the previous two counterfactuals. Figure 5B presents the analogous exercise for noncollege households. 


\section{Figure 6}

\section{Shares Within Education Group}

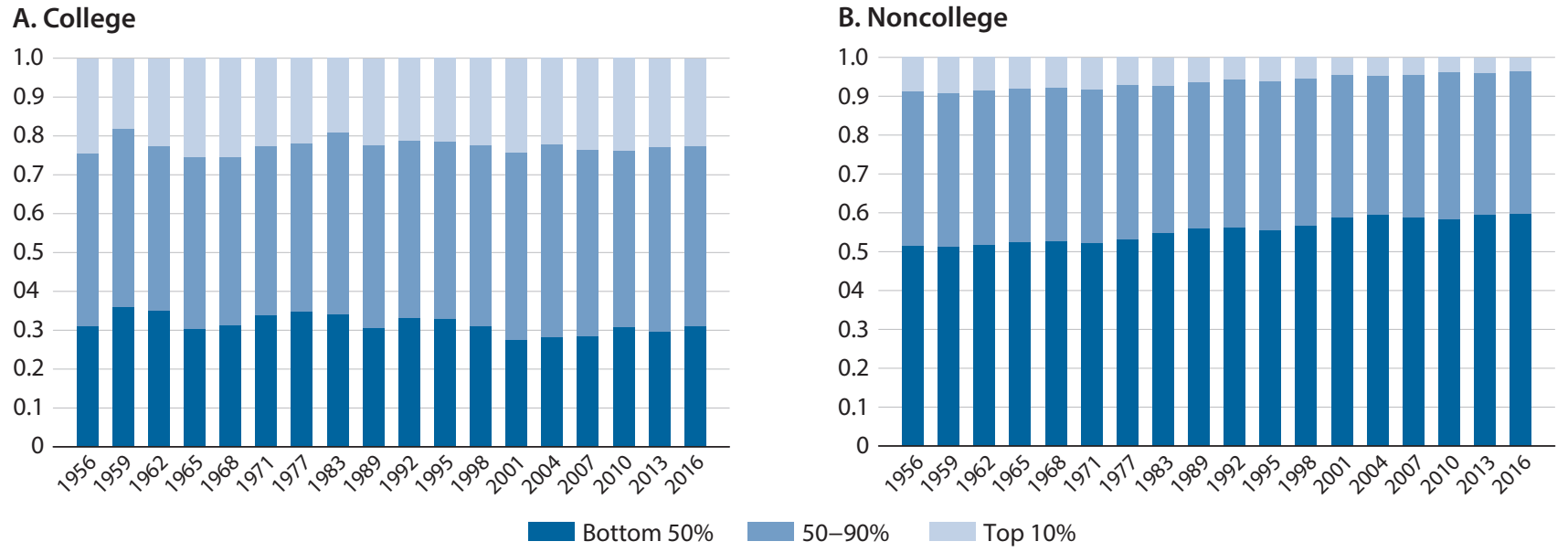

NOTE: The figure shows the shares of households belonging to the bottom 50 percent, 50-90 percent, and top 10 percent of the aggregate wealth distribution for college households (Figure 6A) and noncollege households (Figure 6B) over time.

in Figure $4, \frac{\bar{W}_{e, i, t}}{\bar{W}_{e, i, 71}}$. Based on this decomposition, Figure 5A presents three counterfactuals. The first one assigns the average wealth growth of noncollege households in the top 10 percent of the aggregate wealth distribution, $\frac{\bar{W}_{n c, t o p 10, t}}{\bar{W}_{n c, t o p 10,71}}$, to their college counterparts. The second one holds the share of college households in each wealth group $i$ fixed at its 1971 level, $s_{c, i, 71}$. The third counterfactual combines the two previous counterfactuals. Figure 5B presents the analogous "converse" counterfactuals for noncollege households. For college households, a substantial part of their wealth growth was driven by faster wealth growth within the top 10 percent of the wealth distribution, whereas compositional effects across wealth groups barely mattered. By contrast, both compositional effects and wealth growth in the top 10 percent played an important role for lower wealth growth of noncollege households.

Surprisingly, at first glance, compositional effects across wealth groups played only a minor role in accounting for aggregate wealth growth. To understand why, Figure 6 shows the shares of households belonging to the bottom 50 percent, the middle $50-90$ percent, and the top 10 percent of the aggregate wealth distribution within the group of college households (Figure 6A) and noncollege households (Figure 6B). The finding that compositional changes contribute little to college wealth growth is reflected in the fact that the shares have remained remarkably stable over time. Among college households, on average, around 23 percent belong to the top 10 percent of the aggregate wealth distribution, 45 percent to the middle $50-90$ percent, and 32 percent to the bottom 50 percent. We observe only small fluctuations around these averages over time. For noncollege households, the corresponding shares are 6 percent, 


\section{Figure 7}

\section{Shares of College and Noncollege Households by Wealth Group}

A. Total

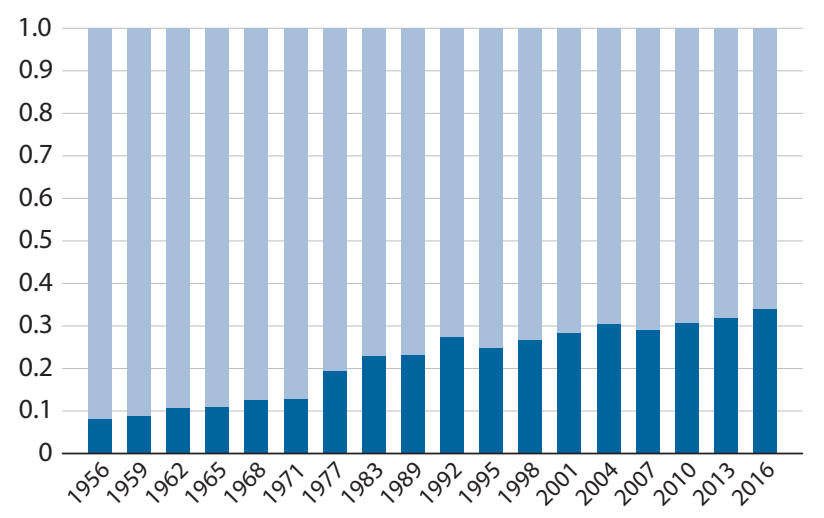

C. $50-90 \%$

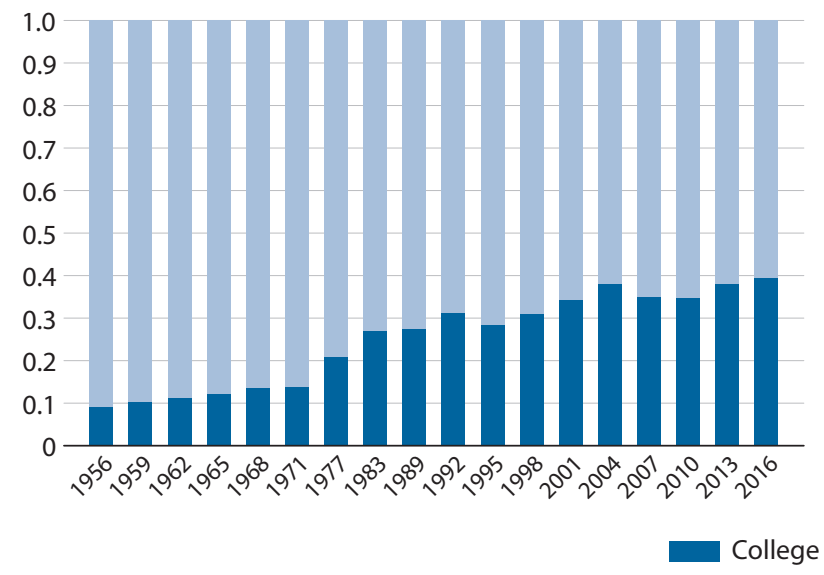

B. Bottom $50 \%$

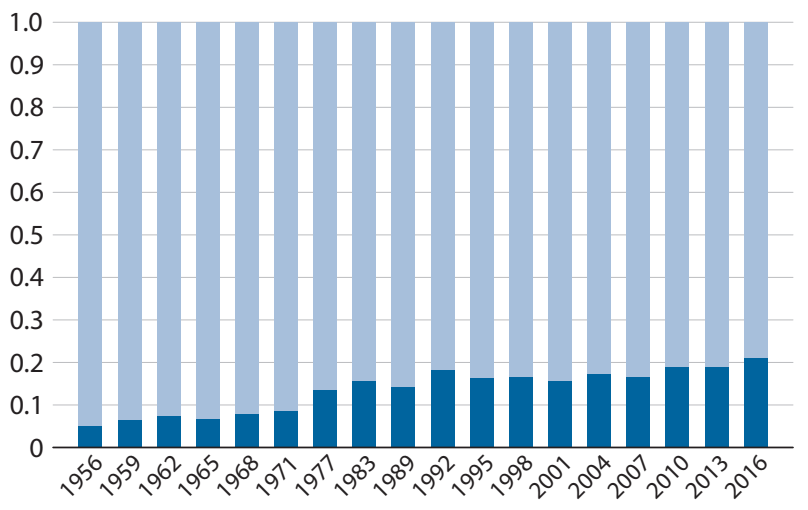

D. Top $10 \%$

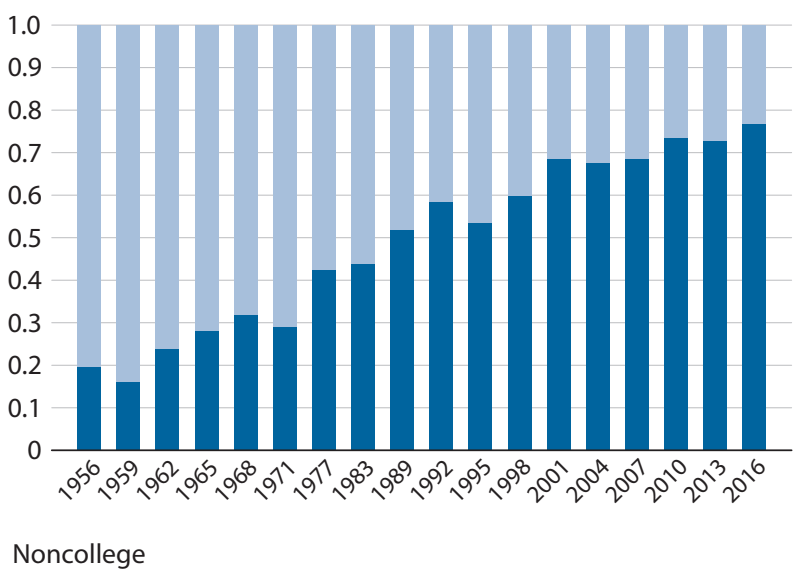

NOTE: The figure shows the shares of college and noncollege households in the entire population and in each group of the aggregate wealth distribution.

38 percent, and 56 percent, but there is a visible trend toward a smaller top 10 percent share and a larger bottom 50 percent share, which is reflected in the results of Figure 5B.

The relative stability of the shares within the group of college households also has important implications for the discussion of education as a means of financial mobility. Our results suggest that obtaining a college degree does not increase the probability of finding oneself in the upper parts of the wealth distribution. A college degree seems to help households to keep pace, but not to climb the wealth ladder.

While Figure 6 slices the data by educational attainment, Figure 7 shows the shares of college and noncollege households within each group of the wealth distribution as well as the full cross section. The overall share of households with a college-educated head has quadrupled 
from 8.1 percent in 1956 to 34 percent in 2016. We find that this increase was distributed evenly across wealth groups, so this trend is consistent with Figure 6. Between 1956 and 2016, the college share rose from 5 percent to 21 percent in the bottom 50 percent of the aggregate wealth distribution, from 9.1 percent to 39.5 percent in the middle $50-90$ percent, and from 19.8 percent to 76.8 percent in the top 10 percent. In other words, it has roughly quadrupled in each group, implying that obtaining a college degree does not necessarily go hand in hand with mobility toward the top of the wealth distribution. The college share is largest in the top 10 percent of the wealth distribution, but having a college degree is not a sufficient condition to reach the top. It is noteworthy that the increase in average college income and wealth, documented above, has taken place while the group of college households grew larger. Accordingly, the total cake has grown faster than the amount of people sharing it. These developments also imply that college households have appropriated larger and larger shares of total wealth and income over time. While noncollege households still accounted for 78 percent of total wealth and 83 percent of total income in 1956, these shares had fallen to 26 percent and 39 percent, respectively, by 2016. As we show next, the wealth and income advantages are particularly large for households in which both spouses hold a college degree (dual-college households).

\subsection{The Role of Marriage Patterns in Wealth and Income Growth}

The share of dual-college households has risen over time. Using Census data, previous research has investigated the importance of assortative mating for income inequality (Eika, Mogstad, and Zafar, forthcoming, and Greenwood et al., 2014 and 2015). Positive (negative) assortative mating refers to a situation when people with the same level of education marry more (less) frequently than what would be expected if marriage patterns were random. The existing studies suggest that positive assortative mating helps to explain cross-sectional income inequality, but hardly contributes to changes of income inequality over time. The SCF+ data allow us to shed light on the role of marriage patterns and assortative mating for wealth in addition to income inequality.

The data show that dual-college households have experienced particularly large increases in income and wealth. In Figure 8A, we see that dual-college households have increased their average income by a factor of around two between 1965 and 2016, while income stagnated for households in which both partners hold only a high school diploma and decreased for households in which both spouses have each completed less than 12 years of schooling. ${ }^{7}$ A qualitatively similar but quantitatively even more pronounced picture emerges for wealth in Figure 8B. Dual-college households have more than quadrupled their wealth, while households without any college-educated spouse have experienced very meager wealth growth.

Figure 8C shows that while dual-college households appropriated only 8 percent of all nonsingle households' income in 1965, the share increased to 49.7 percent in $2016 .{ }^{8}$ However, because the population share of this group also increased over that period, from 4.2 percent to 26.4 percent, the income share of dual-college households relative to their population share hardly changed. A similar result pertains to wealth (Figure $8 \mathrm{D}$ ). In this sense, the increasing share of total income and wealth accruing to (dual-)college households has not been disproportionate. 


\section{Figure 8}

\section{Average Income and Wealth by Education of Spouses}

\section{A. Average income}

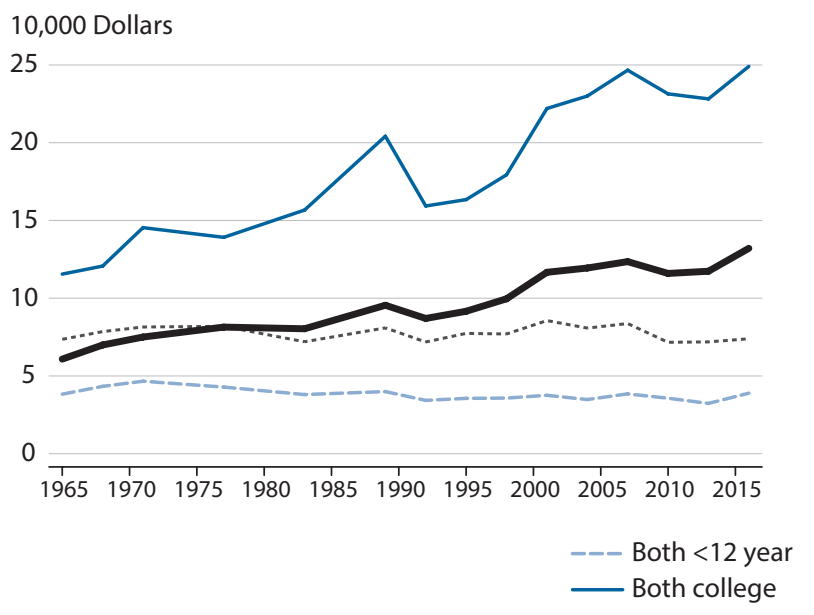

C. Income shares (both college)

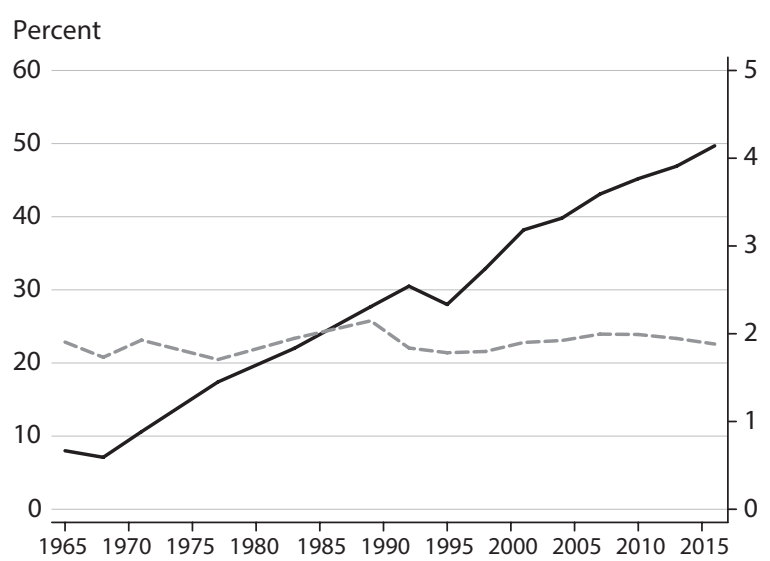

\section{B. Average wealth}

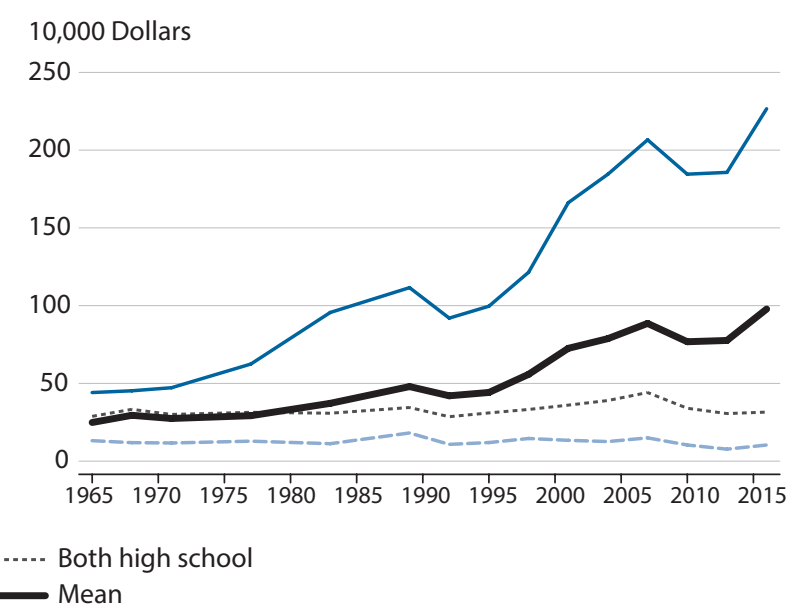

\section{Wealth shares (both college)}

Percent

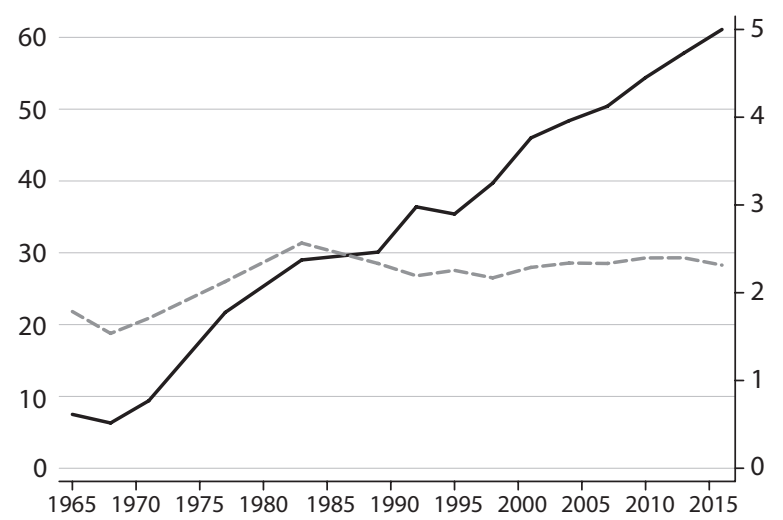

— Income share (left) - -- Relative to population share (right)

NOTE: Figure $8 \mathrm{~A}$ shows average income of households in which both partners have less than 12 years of schooling, a high school diploma, or a college degree, respectively, over time. The thick black line depicts average income for all nonsingle (married or living with partner) households. The male partner was defined as the household head. Figure 8B shows analogous results for net wealth. Figure $8 \mathrm{C}$ shows the share of total income of nonsingle households appropriated by dual-college households, once in percent (black line, left axis), and once relative to this group's population share (gray dashed line, right axis). Figure $8 \mathrm{D}$ shows analogous results for net wealth.

The data also document that dual-college households have appropriated larger shares of income and wealth over time but that this has little to do with assortative mating. Table 1 compares actual marriage patterns with those that would have been observed under random matching based on marginal frequencies. We find that assortative mating has actually decreased for college-educated individuals, whereas it has increased for low-educated individuals. Our 


\section{Table 1}

\section{Marriage Patterns in Selected Years-Actual Data Versus Random Matching}

\begin{tabular}{|c|c|c|c|c|c|c|c|c|c|c|}
\hline \multirow{3}{*}{ Head/spouse } & \multicolumn{3}{|c|}{ Data } & \multirow[b]{2}{*}{ Sum } & \multicolumn{3}{|c|}{ Random } & \multicolumn{3}{|c|}{ Ratio } \\
\hline & $(1)$ & $(2)$ & $(3)$ & & (1) & $(2)$ & (3) & $(1)$ & $(2)$ & (3) \\
\hline & \multicolumn{10}{|c|}{1965} \\
\hline$<12$ Years (1) & 36.6 & 14.6 & 0.4 & 51.6 & 23.5 & 24.9 & 3.2 & 1.6 & 0.6 & 0.1 \\
\hline High school (2) & 8.6 & 26.8 & 1.6 & 37.0 & 16.8 & 17.9 & 2.3 & 0.5 & 1.5 & 0.7 \\
\hline College (3) & 0.3 & 6.9 & 4.2 & 11.4 & 5.2 & 5.5 & 0.7 & 0.1 & 1.3 & 5.9 \\
\hline \multirow[t]{2}{*}{ Sum } & 45.5 & 48.3 & 6.2 & 100 & & & & & & \\
\hline & \multicolumn{10}{|c|}{1977} \\
\hline$<12$ Years (1) & 20.2 & 13.1 & 0.7 & 34.0 & 9.7 & 19.1 & 5.3 & 2.1 & 0.7 & 0.1 \\
\hline High school (2) & 7.7 & 32.7 & 4.7 & 45.1 & 12.8 & 25.3 & 7.0 & 0.6 & 1.3 & 0.7 \\
\hline College (3) & 0.5 & 10.3 & 10.2 & 21.0 & 6.0 & 11.8 & 3.3 & 0.1 & 0.9 & 3.1 \\
\hline \multirow[t]{2}{*}{ Sum } & 28.4 & 56.1 & 15.6 & 100 & & & & & & \\
\hline & \multicolumn{10}{|c|}{1989} \\
\hline$<12$ Years (1) & 11.8 & 10.7 & 0.7 & 23.2 & 4.4 & 14.4 & 4.4 & 2.7 & 0.7 & 0.2 \\
\hline High school (2) & 6.6 & 38.9 & 5.2 & 50.7 & 9.6 & 31.5 & 9.5 & 0.7 & 1.2 & 0.5 \\
\hline College (3) & 0.6 & 12.5 & 12.9 & 26.0 & 4.9 & 16.1 & 4.9 & 0.1 & 0.8 & 2.6 \\
\hline \multirow[t]{2}{*}{ Sum } & 19.0 & 62.1 & 18.8 & 100 & & & & & & \\
\hline & \multicolumn{10}{|c|}{1998} \\
\hline$<12$ Years (1) & 6.9 & 7.6 & 0.2 & 14.7 & 1.7 & 9.2 & 3.8 & 4.0 & 0.8 & 0.1 \\
\hline High school (2) & 4.3 & 44.4 & 7.4 & 56.1 & 6.6 & 35.1 & 14.5 & 0.7 & 1.3 & 0.5 \\
\hline College (3) & 0.5 & 10.5 & 18.3 & 29.3 & 3.4 & 18.3 & 7.6 & 0.1 & 0.6 & 2.4 \\
\hline \multirow[t]{2}{*}{ Sum } & 11.7 & 62.5 & 25.9 & 100 & & & & & & \\
\hline & \multicolumn{10}{|c|}{2007} \\
\hline$<12$ Years $(1)$ & 6.7 & 6.3 & 0.3 & 13.3 & 1.5 & 7.8 & 4.0 & 4.4 & 0.8 & 0.1 \\
\hline High school (2) & 4.4 & 41.0 & 8.2 & 53.6 & 6.1 & 31.4 & 16.1 & 0.7 & 1.3 & 0.5 \\
\hline College (3) & 0.3 & 11.2 & 21.6 & 33.1 & 3.8 & 19.4 & 10.0 & 0.1 & 0.6 & 2.2 \\
\hline \multirow[t]{2}{*}{ Sum } & 11.4 & 58.5 & 30.1 & 100 & & & & & & \\
\hline & \multicolumn{10}{|c|}{2016} \\
\hline$<12$ Years (1) & 5.4 & 6.1 & 1.0 & 12.5 & 1.2 & 6.5 & 4.8 & 4.5 & 0.9 & 0.2 \\
\hline High school (2) & 3.8 & 35.2 & 11.0 & 50.0 & 4.9 & 26.0 & 19.2 & 0.8 & 1.4 & 0.6 \\
\hline College (3) & 0.5 & 10.7 & 26.4 & 37.6 & 3.6 & 19.6 & 14.4 & 0.1 & 0.5 & 1.8 \\
\hline Sum & 9.7 & 52.0 & 38.4 & 100 & & & & & & \\
\hline
\end{tabular}

NOTE: The table shows the relative size (in percent) of marriage groups defined by education of the head and spouse over time. The reference totals are all nonsingle households (married or living with a partner) with information on the educational attainment of both spouses: (1) means less than 12 years of schooling, (2) means high school diploma, and (3) means a college degree. Rows refer to the head, columns to the spouse. The male partner was defined as the household head. The "Data" columns of the table shows each group's relative size in the data. The "Random" columns show the corresponding shares if matching were random. The "Ratio" columns show the ratio of the shares in the data to the shares that would have been obtained with random matching. The counterfactual was computed from marginal frequencies. Reading example: In 1965, 4.2 percent of households had both a head and spouse with a college degree; 6.2 percent of all spouses and 11.4 percent of all heads had a college degree. The share of dual-college households was 5.9 times as large as it would have been with random matching. 
Figure 9

Wealth and Income Ratios: College/Noncollege

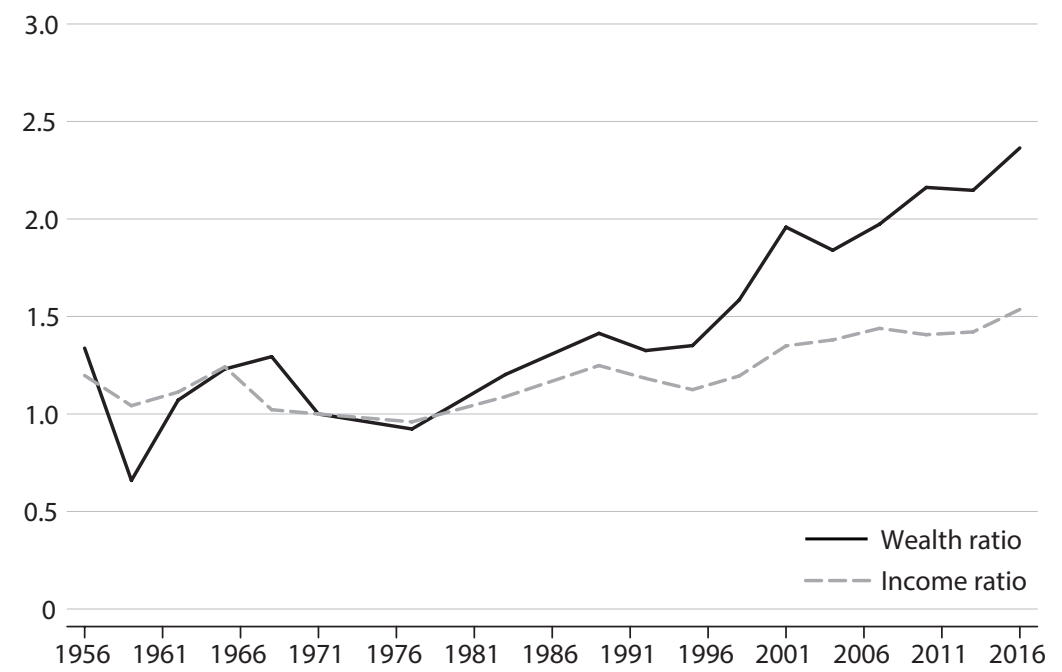

NOTE: The graph shows the ratios of college to noncollege wealth (black line) and income (gray dashed line), respectively, each relative to its level in 1971.

results are both qualitatively and quantitatively consistent with the findings of Eika, Mogstad, and Zafar (forthcoming), who use U.S. data from the March CPS for 1962-2013. ${ }^{9}$ In other words, the fact that we see a larger share of dual-college households nowadays can mainly be attributed to increases in educational attainment, especially among females, rather than changes in preferences and sorting. While there were around 11.4 percent male college graduates in 1965, the share of college graduates among the female partners was only 6.2 percent. The shares increased to 37.6 percent for males and 38.4 percent for females in 2016.

\section{PORTFOLIO COMPOSITION AND ENTREPRENEURSHIP}

The previous section has presented evidence that college households have improved their wealth position substantially compared with noncollege households, which we referred to as an increase in the college wealth premium. In this section, we investigate potential drivers of this development in more detail.

Figure 9 contrasts the increase in the college wealth with the college income premium. 10 The ratio of college to noncollege income was roughly stable until the late 1970s. The ratio of college to noncollege wealth fluctuated somewhat more over this period but did not show any trending behavior. In the early 1980s, both ratios embarked on a largely uninterrupted upward trend. The only exceptions were the early-1990s recession and the burst of the "dot-com bubble" in 2001. The wealth premium has increased considerably more than the income premium, namely by around 135 percent versus 50 percent for the income premium between 1971 and 2016 . 


\section{Figure 10}

\section{Middle-Class Wealth and Income Levels by Decade}
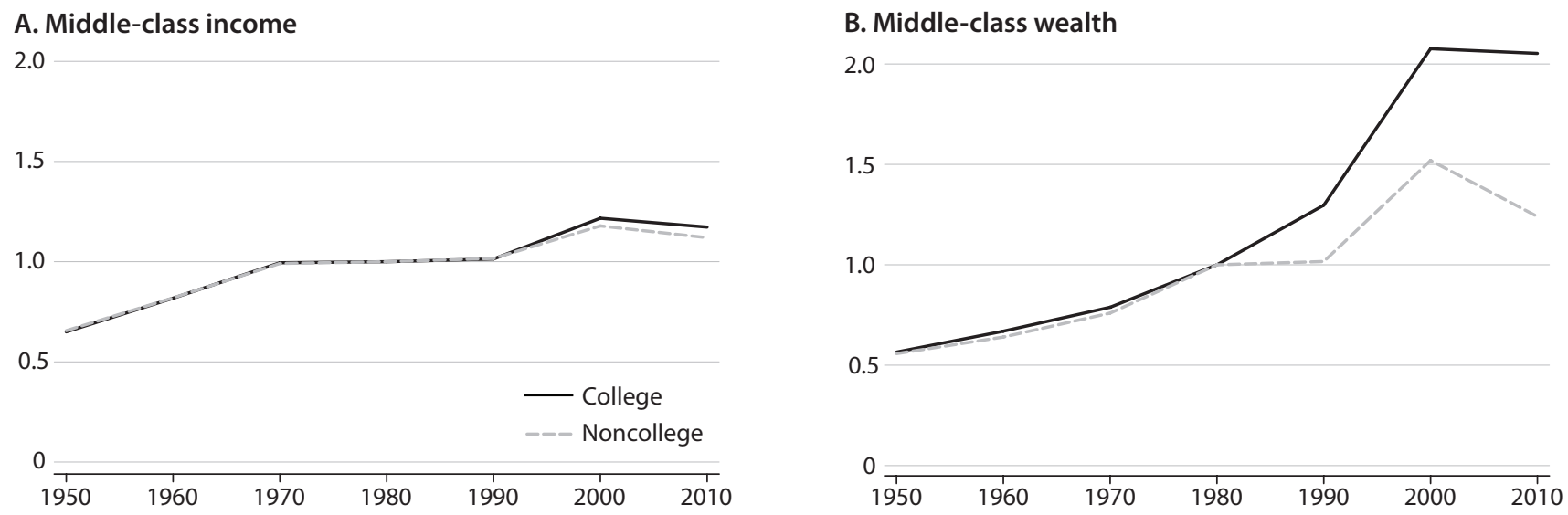

NOTE: The figure shows average income and wealth, respectively, for college and noncollege households, respectively, from the middle 50-90 percent of the aggregate income distribution. Data were averaged across decades and normalized to the 1980s.

The discrepancy in the development of income and wealth becomes even more explicit when we consider only the middle class (50-90 percent) of the income distribution and average the data by decade. $\frac{11}{}$ The results are shown in Figure 10. Even for middle-class households who, by construction, had almost identical income paths, the increase of the college wealth premium since the 1980s stands out. While wealth has doubled for college households, noncollege households with the same income trends saw their wealth increasing only by 25 percent. Which role do demographic shifts play for the observed phenomena? So far, we have looked at unconditional averages. To obtain an estimate of the "college wealth effect" net of potential confounders such as demographics, we estimate the following micro-level regression:

$$
W_{i t}=\beta_{0}+\beta_{1} c_{i t}+\sum_{t>1956} \beta_{2, t} \mathbb{I}[\text { year }=t] \cdot c_{i t}+\sum_{t>1956} \beta_{3, t} \mathbb{I}_{[\text {year }=t]}+\Gamma^{\prime} X_{i t}+\xi_{i t} .
$$

$W_{i t}$ denotes wealth of household $i$ in survey wave $t, \mathbb{I}_{[y e a r=t]}$ are survey wave fixed effects for $t=\{1959,1962, \ldots, 2016\}$, and $c_{i t}$ is an indicator for whether the head has a college degree. The control vector $X_{i t}$ includes total household income, a full set of age dummies, a dummy for whether the household includes children, and an indicator for whether the head is married. As a baseline specification, we estimate this regression on the entire sample. As a robustness check, we also estimate it on a restricted sample that is limited to households in the 50-90 percent group of the aggregate income distribution. This restriction can be interpreted as an additional nonparametric way of controlling for income.

Figure 11 illustrates the results, and the underlying coefficient estimates are summarized in Table B3. The college wealth effect $\left(\beta_{1}+\beta_{2, t}\right)$ is clearly visible from the $1980 \mathrm{~s}$ on. The figure also illustrates that college wealth tends to be hit more severely in recessions, which tend to reduce the college wealth premium. For the middle-class income sample, the college wealth 


\section{Figure 11}

\section{Regression Evidence}

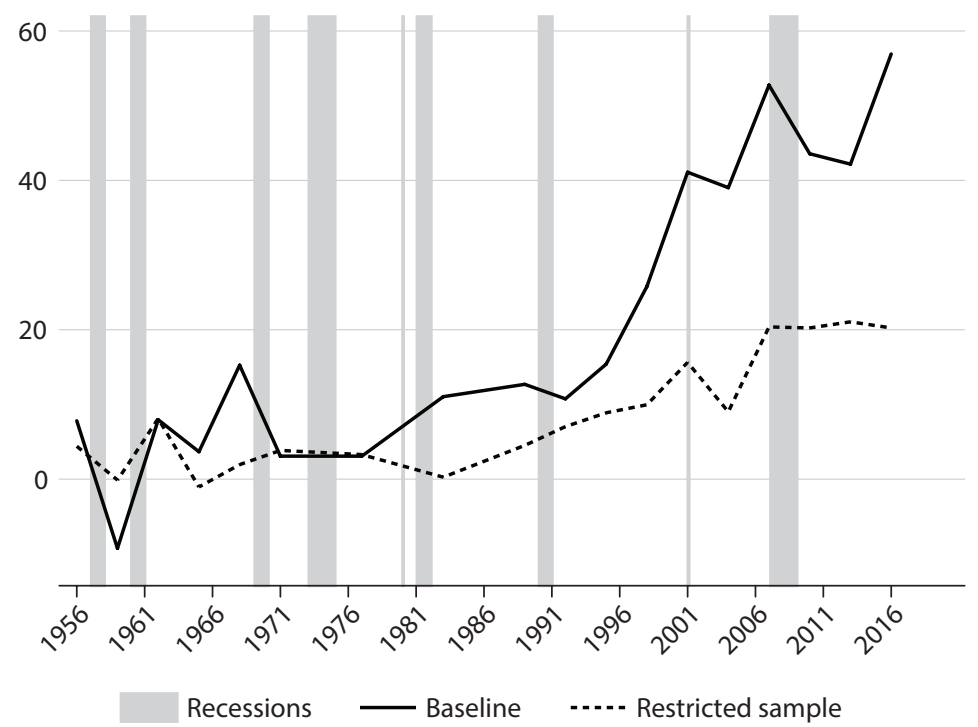

NOTE: The graph shows the advantage of having a college degree $\left(\beta_{1}+\beta_{2}\right)$ over time. The black line refers to the baseline in (2). The dashed line presents the results for a restricted sample including only households from the middle 50-90 percent of the aggregate income distribution. The gray bars indicate recessions as determined by the National Bureau of Economic Research.

effect is smaller in size but still clearly visible since the 1980s. Indeed, the college wealth effect is strongest for the top 10 percent of the income distribution but also visible for the bottom 90 percent (Figure A3 in the appendix). By contrast, the college income effect is much smaller and entirely driven by the top 10 percent of the aggregate income distribution.

\subsection{Portfolio Heterogeneity}

In workhorse models of wealth inequality following the early work of Huggett (1993) and Aiyagari (1994), wealth growth depends on the amount of savings, so that changes in income inequality translate into changes in wealth inequality. However, it is a well-established fact that wealth inequality exceeds income inequality. Economic theory highlights the role of the life cycle, bequests, entrepreneurship, and differential returns on assets to explain this finding (see, e.g., Cagetti and De Nardi, 2008; De Nardi and Fella, 2017; and Benhabib, Bin, and Luo, 2017). Kuhn, Schularick, and Steins (forthcoming) provide further empirical substance to the important role of differences in portfolio choice and associated returns. They illustrate how differences in household portfolios along the wealth distribution, combined with differential asset price growth, can lead to a "decoupling" of the growth of income and wealth.

The SCF+ data allow us to examine the portfolio composition of households with different educational attainment. Figure 12 illustrates that the average portfolios of college and non- 


\section{Figure 12}

\section{Portfolio Shares of College and Noncollege Households}

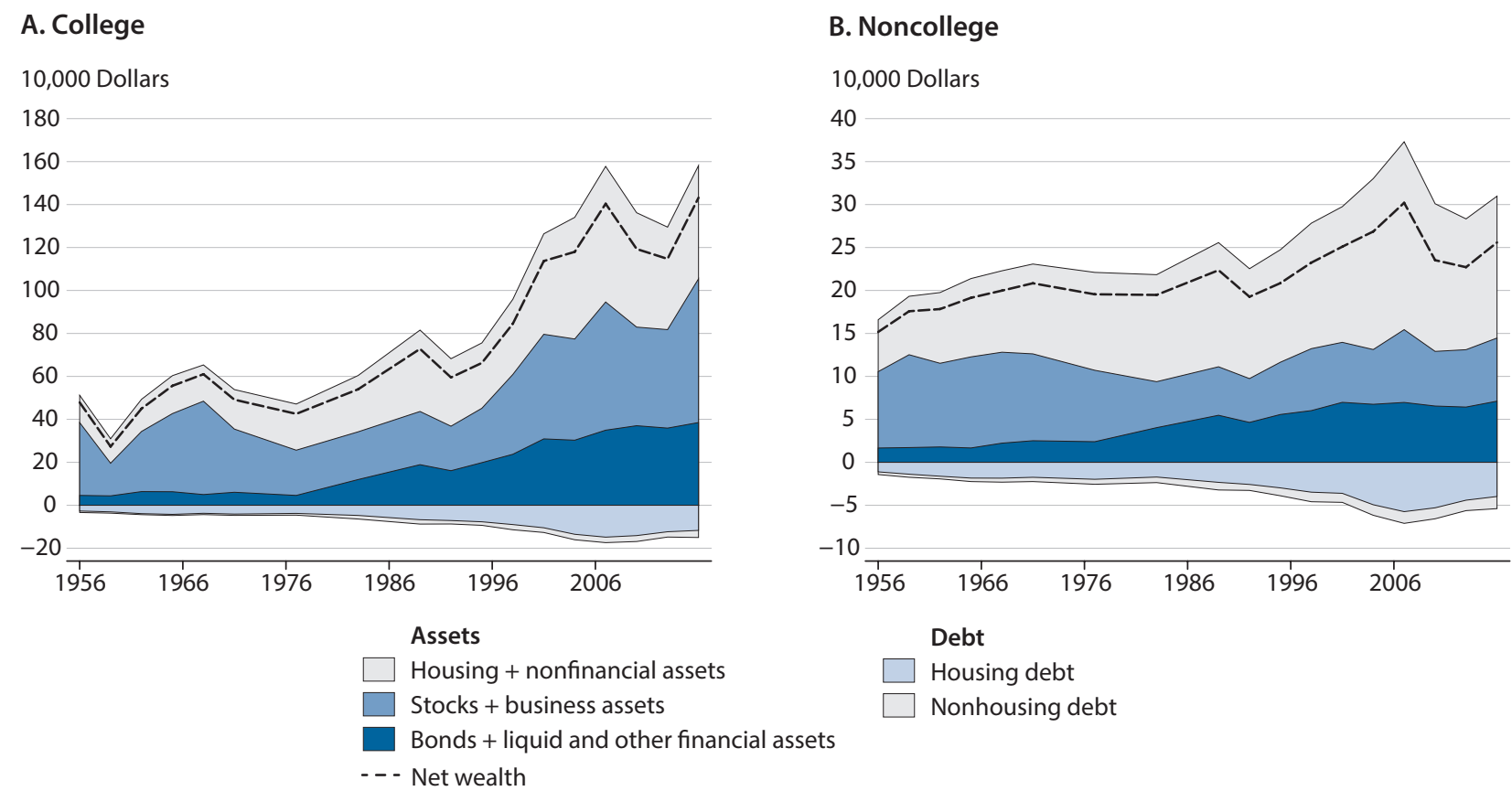

NOTE: Figure 12A shows the portfolio composition of college households. Figure 12B shows the portfolio composition of noncollege households. Housing includes nonresidential real estate. Stocks include mutual fund holdings and other managed assets.

college households do not merely differ in size, but also in composition. In particular, the share of nonfinancial assets is substantially larger for noncollege households. Table B2 in the appendix shows that this high share is mainly accounted for by housing. For instance, the housing portfolio share of noncollege households was 53 percent in 2007, compared with 37.3 percent for college households. By 2016, these shares had slightly decreased to 46.9 percent and 30.9 percent, respectively. By contrast, college households tend to hold larger shares of business wealth and equity than noncollege households.

Kuhn, Schularick, and Steins (forthcoming) show how portfolio differences give rise to differential exposure to asset price changes. In the case of college households, their higher equity portfolio share allowed them to reap higher capital gains due to increasing stock prices over the past 30 years. Figure 13 shows that real equity prices, taken from the Macrohistory Database, have more than tripled since 1989. The figure also illustrates that the increase in stock prices has moved hand in hand with the ratio of college to noncollege equity holdings over this period. As capital gains from asset price changes are unrelated to the development of income, they can help to explain why the college wealth premium has increased substantially more than the college income premium. Indeed, the estimated college wealth advantage is reduced when we control for stock market exposure in our micro regressions (Figure 14). We measure stock price exposure via the portfolio share of equity $s^{e}$ and the real average 


\section{Bartscher, Kuhn, Schularick}

Figure 13

\section{Stock Market Exposure and Equity Prices}

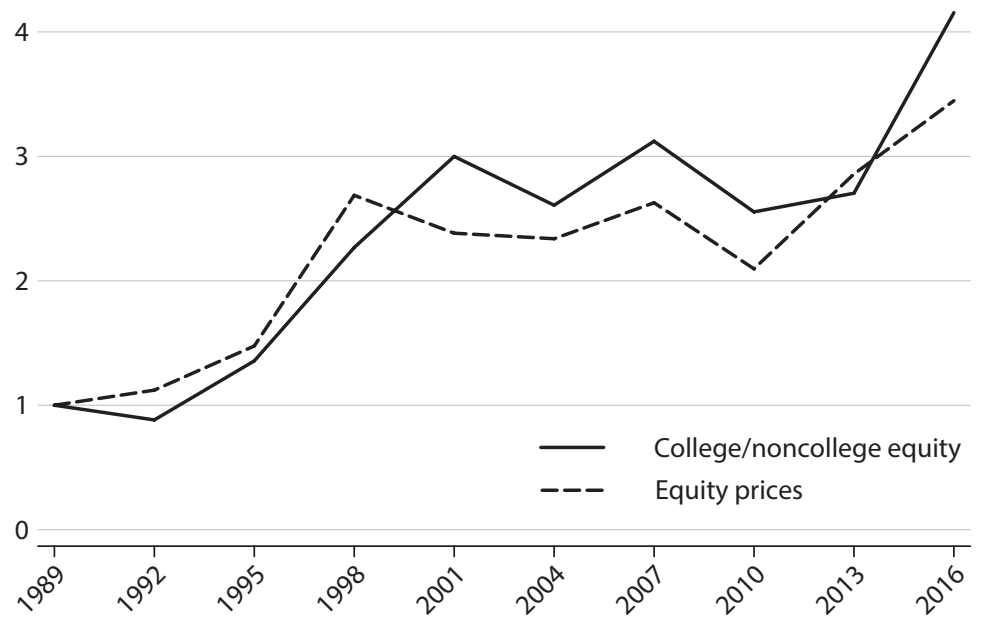

NOTE: The solid line shows the ratio of average college to average noncollege household equity. The dashed line shows the average stock price from the Macrohistory Database, transformed to 2016 dollars. Both series were indexed to 1989. Stocks include mutual fund holdings and other managed assets.

\section{Figure 14}

\section{Controlling for Stock Market Exposure}

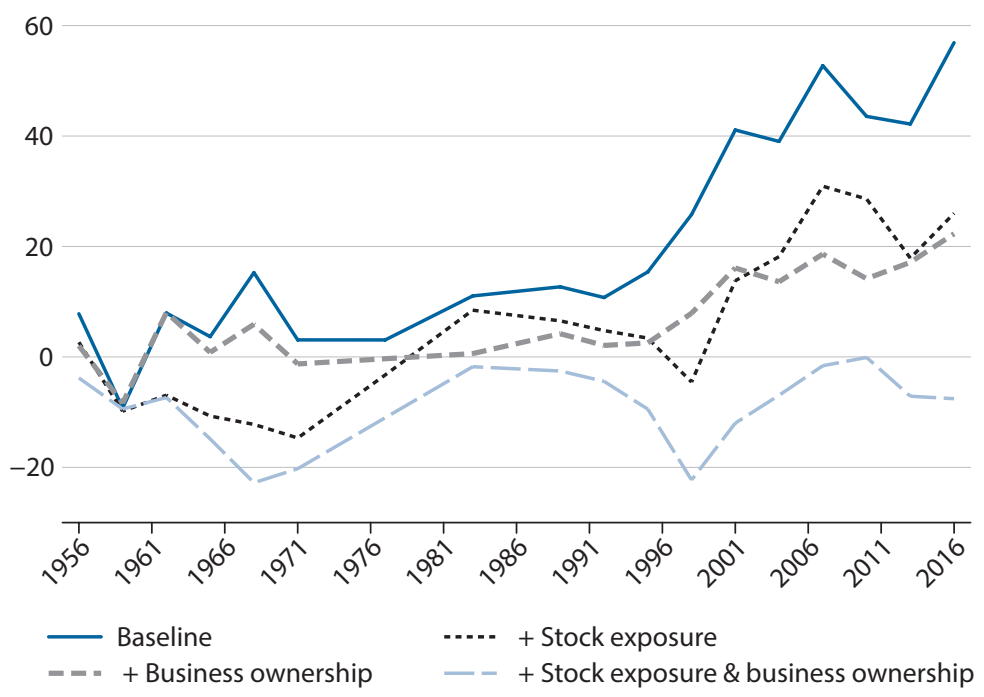

NOTE: The graph shows the advantage of having a college degree $\left(\beta_{1}+\beta_{2, t}\right)$. The solid line repeats the baseline from (2) as a reference. The short-dashed black line presents the results for regression (3); the dashed gray line presents the results for regression (4); and the long-dashed, light-blue line includes the additional controls from both (3) and (4). 
equity price $P^{e}$, included in levels, interacted with each other and interacted with college. More precisely, we estimate the following regression:

$$
\begin{aligned}
W_{i t} & =\beta_{0}+\beta_{1} c_{i t}+\sum_{t>1956} \beta_{2, t} \mathbb{I}_{[\text {year }=t]} \cdot c_{i t}+\sum_{t>1956} \beta_{3, t} \mathbb{I}_{[\text {year }=t]} \\
& +\beta_{4} s_{i t}^{e}+\beta_{5} s_{i t}^{e} \cdot c_{i t}+\beta_{6} s_{i t}^{e} \cdot P_{t}^{e}+\beta_{7} s_{i t}^{e} \cdot P_{t}^{e} \cdot c_{i t}+\Gamma^{\prime} X_{i t}+\epsilon_{i t} .
\end{aligned}
$$

Figure 14 shows that controlling for stock price exposure reduces the college wealth premium substantially, especially during the stock market booms in the 1960s and since the 1990s. The high correlation of college to noncollege equity growth with stock price growth since the 1990s stock market boom suggests that differential stock market exposure via direct stock and mutual fund holdings played a key role for the rapid increase in the college wealth premium since the 1980s.

\subsection{Business Ownership}

While stock price exposure can account for an important share of the observed college wealth premium, there still remains an unexplained wealth growth differential between college and noncollege households. In a second step, we explore the role of business ownership for the observed trends. Motivated by the fact that business wealth has gained importance in the portfolio of college households in recent years, and that business assets, just like equity, are an asset class that is primarily held by the top 10 percent of the aggregate wealth distribution (Kuhn, Schularick, and Steins, forthcoming), we look at the effects of controlling for business ownership.

In equation (3), we included the portfolio share of equity and mutual funds. Fangereng et al. (2018) point out that entrepreneurial skills may affect the whole portfolio via differential returns. Therefore, we include a more general dummy for business ownership, bus $s_{i t}$, instead of the portfolio share of business wealth in this specification. Since there is no general market price for business assets, we interacted the dummy with year fixed effects to allow for variation across time. Apart from these slight changes, the specification follows that in equation (3)

$$
\begin{aligned}
W_{i t}= & \beta_{0}+\beta_{1} c_{i t}+\sum_{t>1956} \beta_{2, t} \mathbb{I}_{[\text {year }=t]} \cdot c_{i t}+\sum_{t>1956} \beta_{3, t} \mathbb{I}_{[\text {year }=t]}+\beta_{4} b u s_{i t}+\beta_{5} b u s_{i t} \cdot c_{i t}+ \\
& \sum_{t>1956} \beta_{6, t} \mathbb{I}_{[\text {year }=t]} \cdot b u s_{i t}+\sum_{t>1956} \beta_{7, t} \mathbb{I}_{[\text {year }=t]} \cdot b u s_{i t} \cdot c_{i t}+\Gamma^{\prime} X_{i t}+\varepsilon_{i t} .
\end{aligned}
$$

The dashed gray line (+ Bus. ownership) in Figure 14 shows the resulting coefficients $\beta_{1}$ and $\beta_{2, t}$. Moreover, we estimate a specification of the regression in which we include the additional controls from (3) and (4) jointly. This specification is shown as the long-dashed, lightblue line (+ Stock exposure \& bus. ownership) in Figure 14. The estimations suggest that also business ownership has contributed to the increase in the college wealth premium. Yet our regressions only show conditional correlations and cannot lay claim to causality. In the following section, we discuss potential underlying mechanisms for the observed correlations. 


\section{Figure 15}

\section{Financial Literacy}

A. By wealth

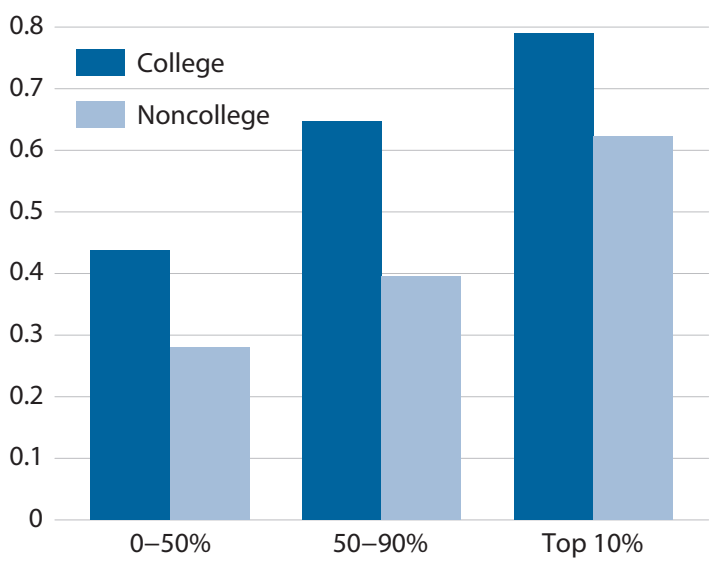

B. By stock and business ownership

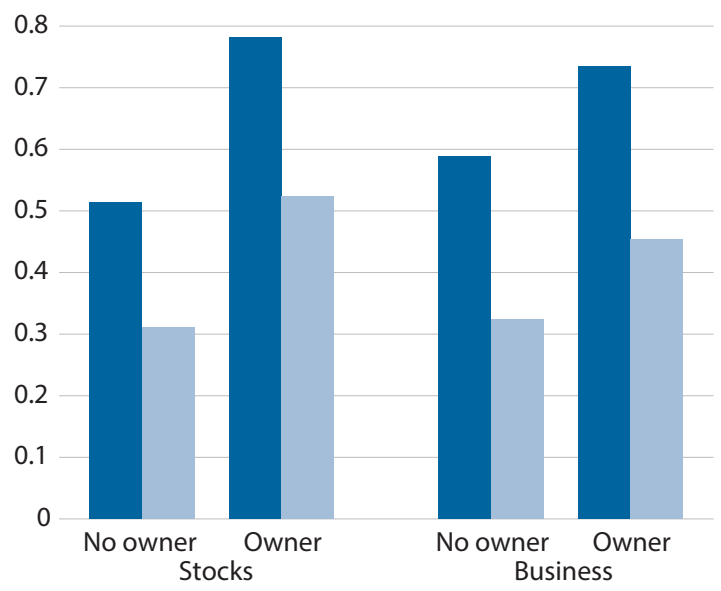

NOTE: Figure 15A shows the shares of college and noncollege households, respectively, who answered all three questions on financial literacy correctly in the 2016 SCF, by wealth group. Figure 15B shows the shares stratified by stock and business ownership instead of wealth.

\section{FINANCIAL LITERACY AND RETURNS ON WEALTH}

Our results suggest that stock market exposure and business ownership are driving forces behind the rise in the college wealth premium. In the following, we explore potential reasons why these factors are important, pointing to promising directions for future research. In particular, we ask which role financial literacy plays for portfolio composition and for differential returns on wealth.

\subsection{Financial Literacy and Portfolio Composition}

One reason why college households hold different assets may be financial literacy. Previous research has consistently established that higher educational attainment is associated with higher levels of financial literacy (see Lusardi and Mitchell, 2011; Lusardi and Mitchell 2014; and Lusardi, Michaud, and Mitchell, 2017). 12 Higher financial literacy can, for example, affect wealth growth through portfolio composition. Typically, financial literacy is measured via three questions that elicit the understanding of compound interest, inflation, and risk diversification (see Lusardi and Mitchell, 2011). Since the 2016 wave, these questions are also part of the SCF. Figure 15A shows the shares of households who answered all three questions correctly, stratified by wealth and education. The figure reveals that financial literacy increases with wealth, and is clearly higher for college than for noncollege households in all wealth groups. Moreover, Figure 15B shows that stock owners do on average have a higher level of financial literacy than nonowners. The same is true for business owners. In a study of Dutch household survey data, Von Gaudecker (2015) shows that low financial literacy leads to return losses due 
to underdiversification in financial assets (unless households seek financial advice). Indeed, the question on risk diversification is the financial literacy question that respondents find most challenging across a wide range of countries (see Lusardi and Mitchell, 2014). In the 2016 SCF, the difference between college and noncollege households is most pronounced for the risk diversification question, with an average share of correct answers of 75.9 percent for college and 55.9 percent for noncollege households. $\frac{13}{}$ Moreover, while we have only looked at direct stock market exposure, this may also impact indirect exposure via pension plans. Lusardi, Michaud, and Mitchell (2017) stress the heightened importance of financial literacy in the United States due to the movement from defined-benefit to defined-contribution plans, such as $401(\mathrm{k}) \mathrm{s}$. This transition started in the 1980s, coinciding with the timing of the widening college wealth premium.

To explore the role of financial literacy, we estimate a regression analogous to the baseline in equation (2) for 2016. When we included the SCF financial literacy measure (which equals 1 if all three questions were answered correctly and zero otherwise) and its interaction with the college indicator, the estimated college effect was reduced by around 40 percent. Yet this result is only suggestive. Further research is necessary to investigate the robustness of the finding and potential transmission mechanisms.

\subsection{Returns on Wealth}

College education might affect wealth accumulation not only through its effect on portfolio allocation across different asset classes, but also via higher returns within a given asset class. For instance, college households might be savvier in picking investments with high returns or low fees. Fagereng et al. (2018) demonstrate that persons with higher levels of education, and especially those with an economics-related college degree, earn higher returns on their wealth and financial assets even conditional on portfolio composition. This suggests that our estimate of the effect of differential asset price exposure from Section 4 might be conservative, given that we applied the average rate of return on stocks for all households.

Apart from financial savvy, Fagereng et al. (2018) also point to entrepreneurial skills as a source of differential returns. Moreover, borrowing constraints can induce entrepreneurs to save substantial amounts and thus become very wealthy (Cagetti and De Nardi, 2006). There is evidence that business ownership is associated with higher education (see, e.g., Hurst and Lusardi, 2004). Consistently, the share of business owners in the SCF+ is higher among college households than among noncollege households in all waves (and conversely, the share of college households is disproportionately high among business owners).

Fagereng et al. (2018) use administrative individual-level data from Norway to construct a measure of returns to financial wealth. To this end, they add income from safe and risky assets and divide it by the average stock of financial and business assets. $\stackrel{14}{ }$ Due to the panel structure of their data, they can use the average of beginning- and end-of-period assets as the denominator, in order to account for changes in the stock of assets over the current period. This is not possible with the SCF, as it consists of repeated cross sections. Moreover, income is reported for the year previous to the survey year.

For these reasons, a similar measure constructed from SCF data is likely to include more measurement error. Keeping this in mind, we construct an analogous proxy for returns based 


\section{Figure 16}

\section{Returns to Financial and Business Wealth}

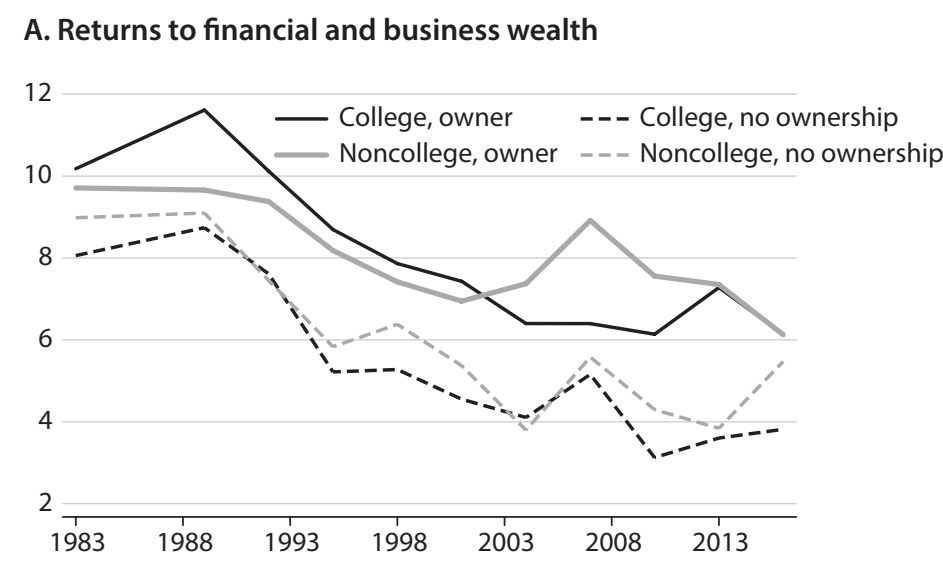

B. Returns to business wealth

A. Returns to financial and business wealth

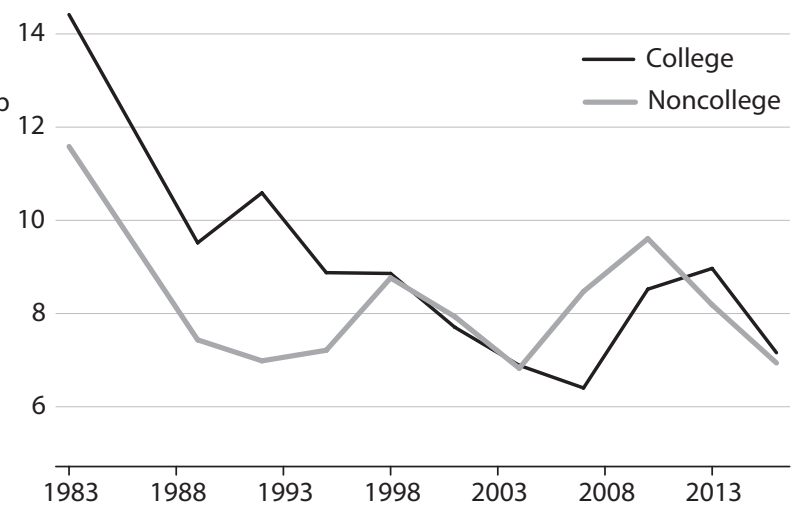

C. Returns to financial wealth by education

D. Returns to financial wealth by ownership
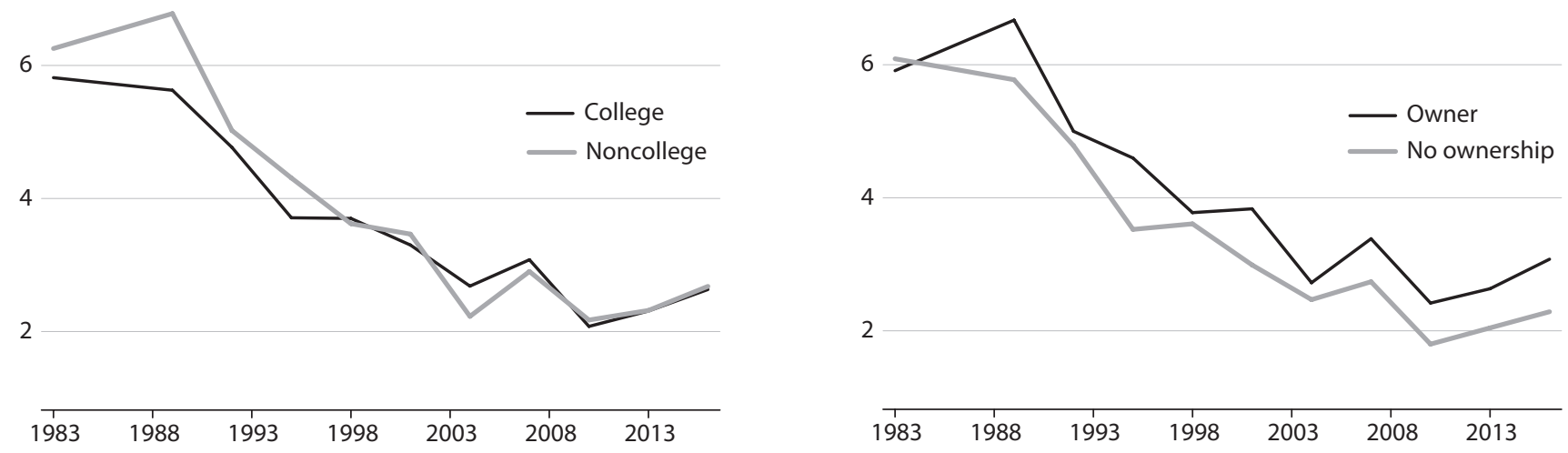

NOTE: Figure 16A shows the proxy for the returns to financial and business wealth by education and business ownership status. Figure 16B shows a similar proxy for business wealth only by education. Figure $16 \mathrm{C}$ shows analogous results for a proxy based on financial wealth only by education. Figure 16D shows the latter measure by business ownership status instead of education. See the text for additional details.

on the modern SCF data, which include detailed information on different components of income. $\frac{15}{}$ For the numerator, we use information on income from farming and business, income from other businesses, rents, trusts or royalties, income from nontaxable investments such as municipal bonds, dividend income, capital gains and losses, and other interest income. For the denominator, we add the amount of stocks, liquid assets and certificates of deposit, bonds, mutual funds, other managed and financial assets, the cash value of life insurances, defined-contribution pension wealth, and business wealth.

Fegereng et al. (2018) exclude persons with less than $\$ 500$ in financial wealth and winsorize the bottom and top 0.5 percent of the returns distribution. We also exclude households with less than $\$ 500$ in financial wealth and drop returns below the 0.5 th and above the 95 th 


\section{Figure 17}

\section{College Business Ownership}

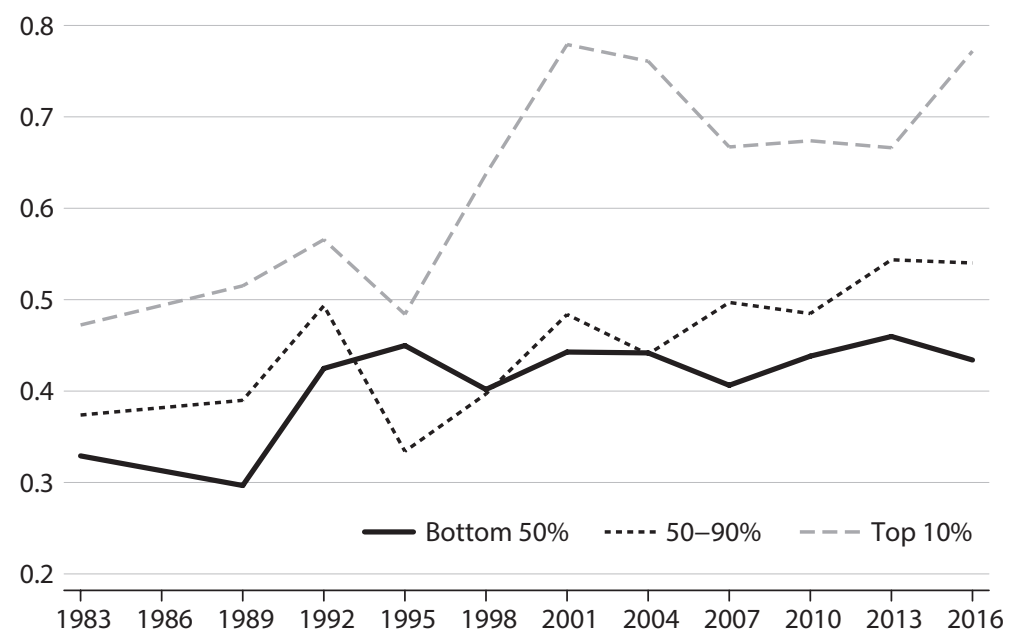

NOTE: The figure shows the shares of college households in the bottom 50 percent, middle 50-90 percent, and top 10 percent of the business wealth distribution (conditional on owning a business).

percentile. The larger trimming region at the top was chosen to take into account that we observe wealth at only one point in time and with a certain lag compared with income. If a household sold most of its financial assets in the year prior to the survey, it would have had high capital income in that year and a relatively low amount of financial assets when surveyed, which would lead to an upward bias in the returns proxy. As Fegereng et al. (2018) report that their results are insensitive to applying an age limit of 20 to 75 year of age, we include households of all ages. Like them, we use real variables before taxes.

The results are presented in Figure 16A. On average, business owners earn higher returns on their financial assets than nonowners. However, the difference between college and noncollege households is limited. Figure 16B presents a similar returns proxy for business wealth only, that is, with income from farming, business, other businesses, rents, trusts or royalties in the numerator, and business wealth in the denominator. While college households had higher returns to business wealth as measured by the proxy until the mid-1990s, the advantage disappears afterward and is even reversed after 2004.

The same comparison for financial wealth is presented in Figure 16C, using the complementary set of income measures in the numerator. Importantly, there is no advantage for college households with respect to this measure, and even a disadvantage in the 1980s. Finally, Figure 16D shows the proxy for returns to financial wealth by business ownership status instead of education. We find that business owners earn slightly higher returns on their nonbusiness wealth as well, in line with the hypothesis of Fagereng et al. (2018) that entrepreneurs' "talent to manage and organize their business" (p. 5) enables them to generate higher returns in general. 
However, while our return proxies are necessarily coarse due to the measurement issues described above, it appears that the return differences between college and noncollege households are small. Yet it is important to keep in mind that a similar rate of return can translate into large level differences if the difference in the underlying asset values is large. Figure 17 shows the shares of college households in the bottom 50 percent, middle 50-90 percent, and top 10 percent of the business wealth distribution, conditional on owning a business. The college share is particularly high in the top 10 percent group, and has increased from slightly below 50 percent to almost 80 percent between 1983 and 2016 .

Based on the existing literature and our explorative results presented in this section, it seems plausible that the interaction of educational attainment, financial literacy, and business acumen has played an important role in shaping the differential development of college and noncollege wealth. However, portfolio composition, not differential returns between college and noncollege households in the same asset class, appears to play the dominant role.

\section{CONCLUSION}

This article documents the evolution of U.S. college and noncollege income and wealth over six decades using newly compiled long-run data at the household level. We corroborate that the college income premium has increased substantially since the 1980s. Yet, though the college income premium has increased substantially, the college wealth premium has risen even more. Since the 1980s, college households have outpaced noncollege households by a factor of 2.5 in terms of wealth growth. We provide evidence that especially households with two college-educated spouses could appropriate large amounts of wealth. However, we confirm previous evidence that this is not related to assortative mating, but rather to rising educational attainment. We find that portfolio choices and the resulting exposure to asset price changes played a crucial role for the observed trends. Using the asset information in the SCF+, we uncover systematic differences in the size and composition of college versus noncollege household portfolios. Building on insights from previous research, we study the combined role of portfolio choices and asset price changes for the evolution of the wealth distribution. Our results suggest that college households could reap large capital gains from stock market booms owing to the higher equity share in their portfolios. This explanation is consistent both with the fact that college wealth grew faster than noncollege wealth, and that college wealth grew faster than college income, since capital gains from asset price changes are not directly related to other sources of income. Moreover, we provide suggestive evidence that the increase in the college wealth premium is related to business ownership.

In the last part of the article, we discuss potential reasons for the importance of differential asset price exposure and capital gains such as financial literacy and entrepreneurial skills. Both can affect wealth accumulation via portfolio choice and differential returns. These factors also interact with institutional features such as the change from defined-benefit to definedcontribution pension plans. Further research will be needed to disentangle different hypotheses for the rising college wealth premium and establish causal relationships. 


\section{APPENDIX}

\section{A. Supplementary Figures}

\section{Figure A1}

\section{Comparison to Census Data}

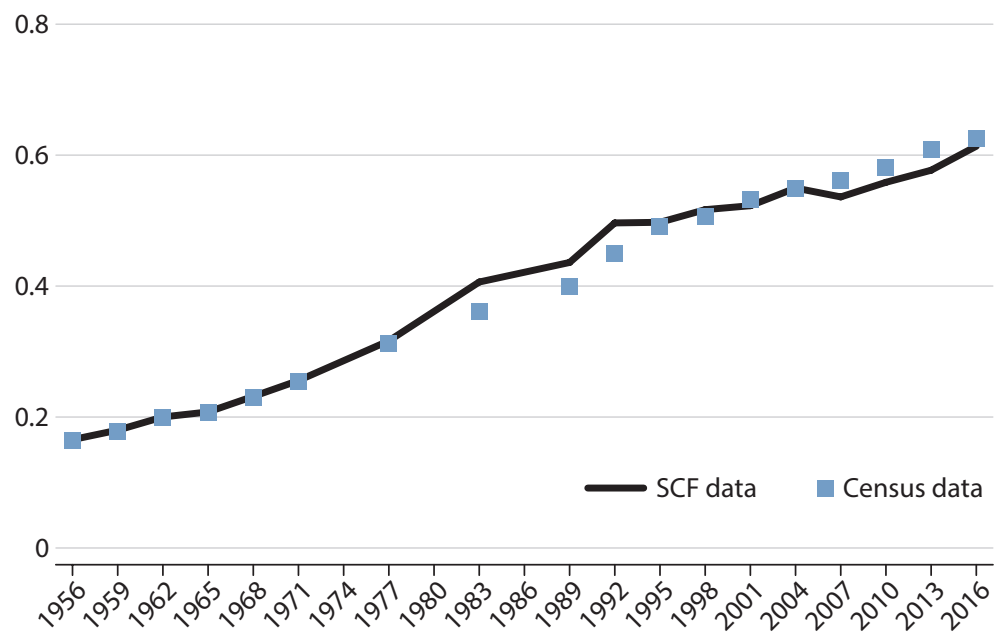

NOTE: The figure shows the share of households in the SCF+ data whose head has at least obtained some college education compared with the share in the CPS for the period 1962-2016 and the share from the U.S. decennial censuses for 1950 and 1960. Intermediate data points were obtained by linear interpolation.

\section{Figure A2}

\section{Wealth-to-Income Ratios Excluding Pensions}

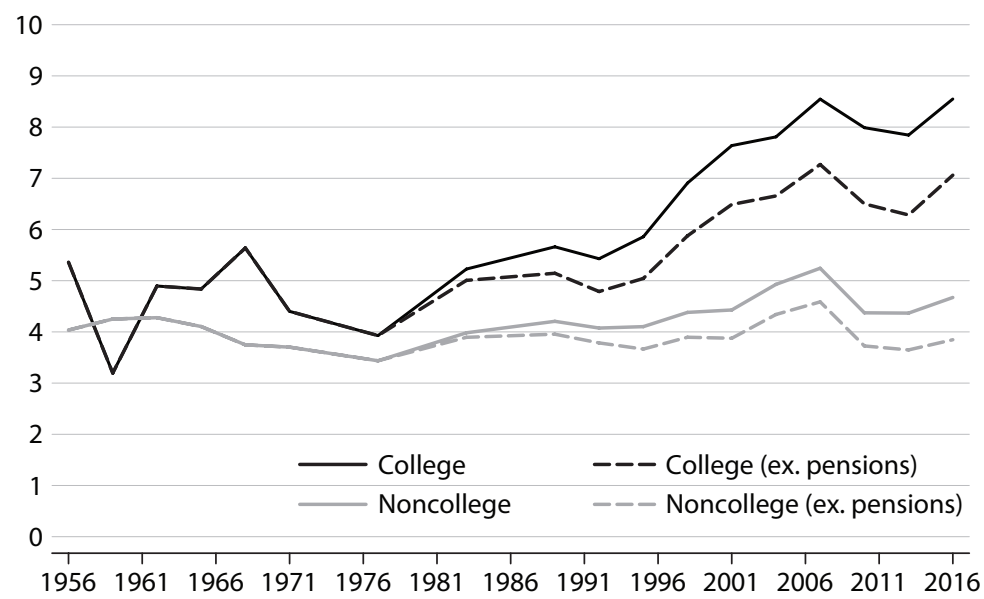

NOTE: The figure shows the ratio of average net wealth to average income for college and noncollege households. The solid lines replicate the baseline from Figure 3 for comparison. The dashed lines show average net wealth net of pensions relative to average income. 


\section{Bartscher, Kuhn, Schularick}

\section{Figure A3}

\section{Regression Coefficients: Advantage of College Within Income Groups}

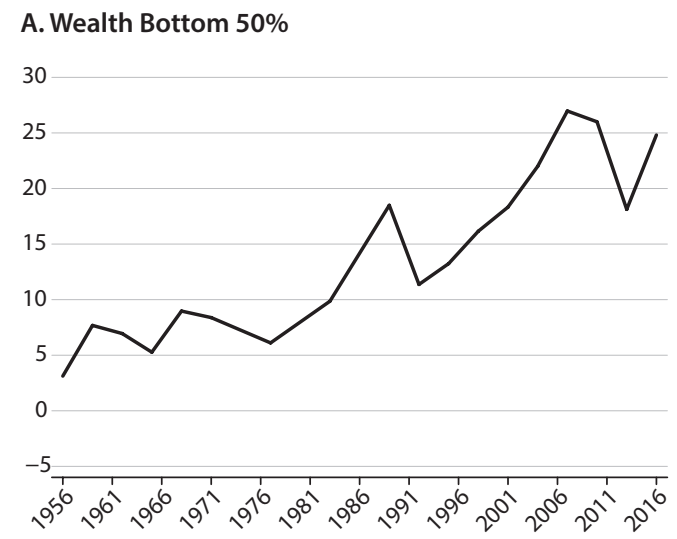

\section{B. Income Bottom 50\%}

4

3

2

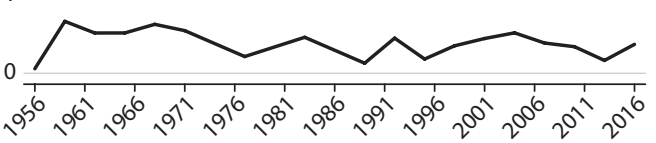

C. Wealth $50-90 \%$

D. Income $50-90 \%$

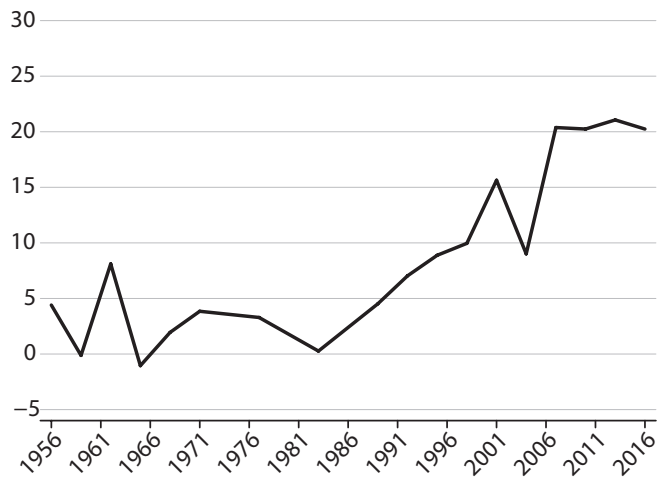

5

4

3

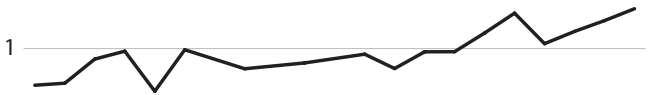

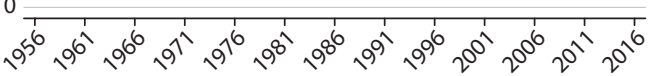

\section{E. Wealth Top $10 \%$}

F. Income Top 10\%
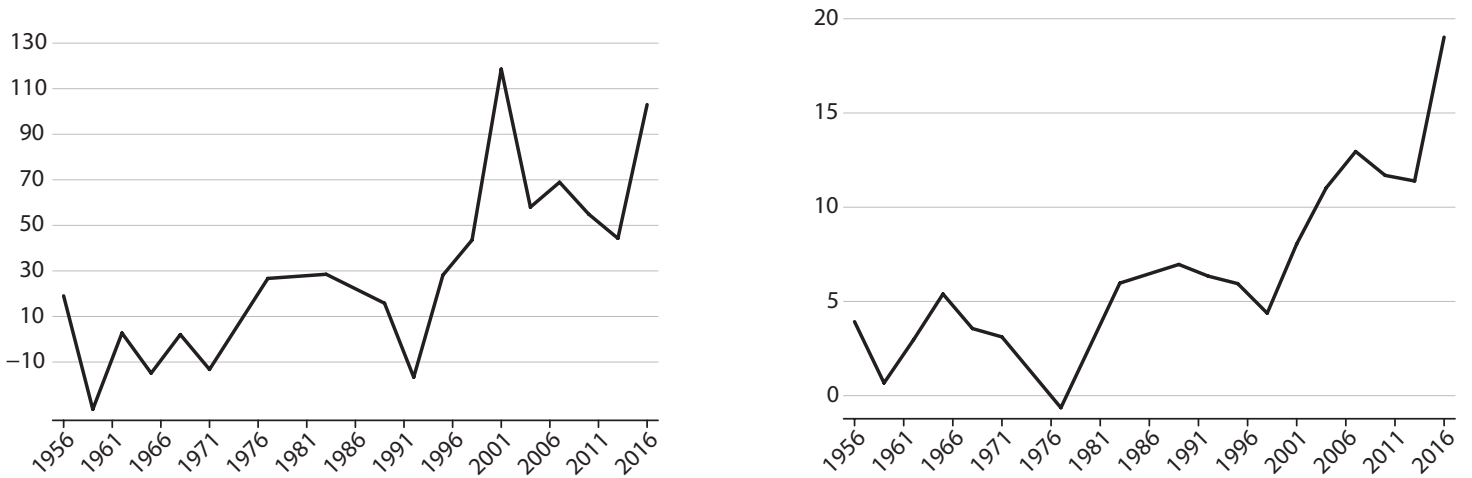

NOTE: The figure shows the advantage of having a college degree $\left(\beta_{1}+\beta_{2, t}\right)$ within the bottom 50 percent, $50-90$ percent, and top 10 percent of the aggregate income distribution over time. The dependent variable is wealth for the left panels and income for the right panels. 


\section{B. Supplementary Tables}

\section{Table B1}

\section{Comparison of Households with College versus Some College}

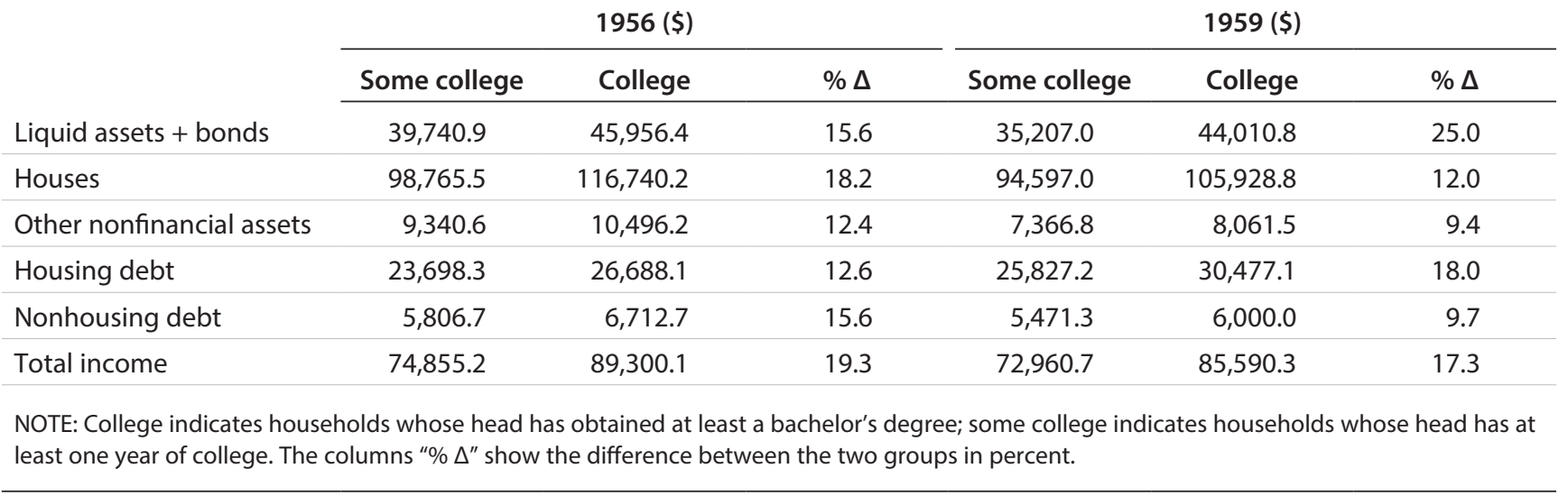

\section{Table B2}

\section{Portfolio Shares for College and Noncollege Households (percent)}

Other nonfinancial assets Housing Business

$\begin{array}{cc}\text { Liquid } & \text { Other } \\ \text { assets }+ \text { bonds } & \text { financial assets }\end{array}$

\begin{tabular}{|c|c|c|c|c|c|c|}
\hline 1956 & 2.0 & 22.8 & 33.3 & 32.9 & 9.0 & - \\
\hline 1965 & 1.3 & 28.0 & 26.1 & 34.2 & 10.5 & - \\
\hline 1977 & 2.9 & 42.7 & 20.1 & 24.5 & 9.8 & - \\
\hline 1989 & 4.6 & 41.8 & 20.9 & 9.5 & 10.7 & 12.5 \\
\hline 1998 & 3.9 & 32.6 & 20.5 & 18.3 & 7.3 & 17.5 \\
\hline 2007 & 2.7 & 37.3 & 22.5 & 15.3 & 6.4 & 15.8 \\
\hline \multirow[t]{2}{*}{2016} & 2.4 & 30.9 & 22.0 & 20.3 & 7.1 & 17.2 \\
\hline & \multicolumn{5}{|c|}{ B. Noncollege } & \\
\hline 1956 & 3.2 & 33.2 & 32.4 & 21.1 & 10.1 & - \\
\hline 1965 & 3.0 & 39.6 & 23.5 & 26.0 & 7.8 & - \\
\hline 1977 & 4.1 & 47.4 & 32.4 & 5.2 & 10.9 & - \\
\hline 1989 & 6.4 & 50.1 & 18.1 & 4.0 & 12.4 & 9.0 \\
\hline 1998 & 6.5 & 46.0 & 14.7 & 11.2 & 8.6 & 13.1 \\
\hline 2007 & 5.6 & 53.0 & 16.6 & 6.1 & 6.1 & 12.6 \\
\hline 2016 & 6.4 & 46.9 & 17.1 & 6.6 & 6.6 & 16.4 \\
\hline
\end{tabular}

NOTE: Equity includes mutual fund holdings and other managed assets. 
Bartscher, Kuhn, Schularick

\section{Table B3}

Regression Results: College Effect $\left(\beta_{1}+\beta_{2, t}\right)$ by Year

\begin{tabular}{|c|c|c|c|c|c|}
\hline & Baseline & Middle-class sample & + Stock exposure & $\begin{array}{l}+ \text { Business } \\
\text { ownership }\end{array}$ & + Stock \& business \\
\hline 1956 & $7.82(0.126)$ & $4.41 *(0.053)$ & $2.66(0.559)$ & $2.02(0.634)$ & $-3.81(0.292)$ \\
\hline 1959 & $-9.26 * * *(0.007)$ & $-0.12(0.943)$ & $-9.83^{* * *}(0.003)$ & $-8.37^{* * *}(0.003)$ & $-9.43^{* * *}(0.001)$ \\
\hline 1962 & $7.95(0.203)$ & $8.11(0.159)$ & $-6.93(0.218)$ & $8.05(0.145)$ & $-7.35(0.137)$ \\
\hline 1965 & $3.67(0.695)$ & $-1.05(0.645)$ & $-10.71(0.210)$ & $0.83(0.897)$ & $-14.85^{* * *}(0.005)$ \\
\hline 1968 & $15.26^{* *}(0.049)$ & $1.95(0.304)$ & $-12.22^{* *}(0.037)$ & $5.91(0.391)$ & $-22.78^{* * *}(0.000)$ \\
\hline 1971 & $3.09(0.579)$ & $3.85(0.278)$ & $-14.68^{* * *}(0.003)$ & $-1.27(0.759)$ & $-20.25^{* * *}(0.000)$ \\
\hline 1977 & $3.08(0.589)$ & $3.29(0.167)$ & $-3.26(0.541)$ & $0.00^{* * *}(0.000)$ & $0.00^{* * *}(0.000)$ \\
\hline 1983 & $11.05^{* *}(0.015)$ & $0.27(0.868)$ & $8.46^{*}(0.053)$ & $0.61(0.843)$ & $-1.77(0.543)$ \\
\hline 1989 & $12.69 * *(0.028)$ & $4.52(0.141)$ & $6.53(0.233)$ & $4.21(0.274)$ & $-2.55(0.483)$ \\
\hline 1992 & $10.76^{* *}(0.011)$ & $7.03^{* * *}(0.001)$ & $4.77(0.218)$ & $2.08(0.502)$ & $-4.42(0.110)$ \\
\hline 1995 & $15.39^{* * *}(0.001)$ & $8.88^{* * *}(0.000)$ & $3.42(0.408)$ & $2.54(0.478)$ & $-9.45^{* * *}(0.003)$ \\
\hline 1998 & $25.78^{* * *}(0.000)$ & $9.96^{* * *}(0.000)$ & $-4.55(0.309)$ & $7.91 * *(0.046)$ & $-22.28^{* * *}(0.000)$ \\
\hline 2001 & $41.09 * * *(0.000)$ & $15.64^{* * *}(0.000)$ & $13.81^{* *}(0.019)$ & $16.11^{* * *}(0.002)$ & $-11.99^{* * *}(0.005)$ \\
\hline 2004 & $39.02^{* * *}(0.000)$ & $9.01^{* * *}(0.006)$ & $18.15^{* * *}(0.002)$ & $13.62^{* * *}(0.003)$ & $-6.94 *(0.068)$ \\
\hline 2007 & $52.75^{* * *}(0.000)$ & $20.38^{* * *}(0.000)$ & $30.92^{* * *}(0.000)$ & $18.62^{* * *}(0.000)$ & $-1.60(0.713)$ \\
\hline 2010 & $43.56^{* * *}(0.000)$ & $20.24^{* * *}(0.000)$ & $28.60 * * *(0.000)$ & $14.17^{* * *}(0.003)$ & $-0.09(0.983)$ \\
\hline 2013 & $42.17^{* * *}(0.000)$ & $21.06 * * *(0.000)$ & $17.89^{* * *}(0.001)$ & $17.14^{* * *}(0.000)$ & $-7.11 *(0.051)$ \\
\hline 2016 & $56.91^{* * *}(0.000)$ & $20.24^{* * *}(0.000)$ & $26.01^{* * *}(0.000)$ & $22.29^{* * *}(0.000)$ & $-7.57^{*}(0.061)$ \\
\hline $\mathrm{N}$ & 89,571 & 34,297 & 86,154 & 89,571 & 86,154 \\
\hline$R^{2}$ & 0.255 & 0.135 & 0.264 & 0.270 & 0.278 \\
\hline
\end{tabular}

NOTE: The dependent variable is net wealth. The controls include survey wave fixed effects, total household income, a full set of age dummies, a kids dummy, and an indicator for marital status. The "Baseline" columns refer to the specification in (2), and the "Middle-class sample" column presents the same regression for the middle 50-90 percent of the aggregate income distribution. The specification "+ Stock exposure" includes the additional controls from (3); "+ Business ownership" includes the additional controls from (4); and "+Stock \& business," which is stock exposure plus business ownership, includes the additional controls from both (3) and (4). Multiply imputed observations were averaged for the regressions. $p$-values are given in parentheses. ${ }^{*} p<0.1,{ }^{* *} p<0.05,{ }^{* * *} p<0.01$. 


\section{NOTES}

1 Note that total household income in the SCF+ is defined net of capital gains.

2 Parental income and wealth may even affect educational outcomes beyond assistance to tap one's full skill potential. Looking at the income of U.S. households, Reeves and Howard (2013) find evidence of "glass floors" in educational outcomes: Children from high-income households tend to do better in terms of education and income than their skills would suggest. The authors stress that wealth is likely to play an important role beyond income. Certainly, the persistence of education and wealth across generations and their interaction are important topics for further research.

$\underline{3}$ Throughout the paper, demographic information will always refer to the household head, if not otherwise stated. In the case of married couples, the household head is typically male.

4 As noted, the reweighting was done based on the share of households with at least some college. A comparison of the SCF+ and census data with respect to this measure is provided in Figure A1.

5 The ratios reported throughout the article are ratios of averages (as opposed to averages of ratios).

$\underline{6}$ By contrast, the college wealth gap has increased in all parts of the aggregate income distribution. The corresponding decomposition is available from the authors upon request.

7 Information on the spouse's educational attainment is only available since 1965.

$\underline{8}$ Nonsingle households comprise marriage and cohabitation. We find very similar results when only considering married households.

9 Eika, Mogstad, and Zafar (forthcoming) demonstrate the robustness of these patterns to accounting for sorting by age and changes in the probability of marriage by education level, as well as to different measures of assortative mating.

10 Note that Figure 3 showed wealth-to-income ratios.

11 Note that our results in the following sections always refer to the full sample and not the "middle class" sample unless explicitly stated otherwise.

12 Lusardi, Michaud, and Mitchell (2011) demonstrate that this can actually be an individually optimal outcome, as households with different levels of education have different life-cycle income paths, which entail different incentives to save. Given that financial knowledge helps to earn higher returns on savings, this creates different incentives to invest in financial literacy.

13 The corresponding share for the question on interest compounding are 86 percent and 73 percent, respectively, and for the question on real interest rates 86.7 percent and 72.9 percent, respectively.

14 They consider the following income components: interest income earned on bank deposits and bond yields, yields from risky assets held abroad and outstanding claims and receivables, yields from mutual funds, yields from directly held listed shares (dividends and accrued capital gains), and yields from all private equity holdings (distributed dividends and the individual share of retained profits). Financial wealth includes bank deposits, money market funds, bond mutual funds, government and corporate bonds, stocks and mutual fund shares, the value of shares in private businesses and other unlisted shares, and the value of risky assets held abroad and of outstanding claims and receivables.

15 Fagereng et al. (2018) also construct a proxy for returns to net worth. As this measure requires information on interest payments on all debt, which is so far neither included in the SCF+ nor the readily available extracts of the modern SCF, we decided to focus on returns to financial and business wealth.

\section{REFERENCES}

Aiyagari, S.R. "Uninsured Idiosyncratic Risk and Aggregate Saving." Quarterly Journal of Economics, 1994, 109, pp. 659-84; https://doi.org/10.2307/2118417.

Bartscher, A.K.; Kuhn, M.; Schularick, M. and Steins, U.I. “Modigliani Meets Minsky: American Household Debt, 19492016." Unpublished manuscript, 2019. 


\section{Bartscher, Kuhn, Schularick}

Benhabib, J.; Bisin, A. and Luo, M. "Earnings Inequality and Other Determinants of Wealth Inequality." American Economic Review, 2017, 107, pp. 593-97; https://doi.org/10.1257/aer.p20171005.

Bricker, J.; Dettling, L.J.; Henriques, A.; Hsu, J.W.; Jacobs, L.; Moore, K.B.; Pack, S.; Sabelhaus, J.; Thompson, J. and Windle, R.A. "Changes in U.S. Family Finances from 2013 to 2016: Evidence from the Survey of Consumer Finances." Federal Reserve Bulletin, September 2017, 103; https://www.federalreserve.gov/publications/2017-September-changes-in-us-family-finances-from-2013-to-2016.htm.

Cagetti, M. and De Nardi, M. "Entrepreneurship, Frictions, and Wealth.” Journal of Political Economy, 2006, 114, pp. 835-70; https://doi.org/10.1086/508032.

Cagetti, M. and De Nardi, M. "Wealth Inequality: Data and Models." Macroeconomic Dynamics, 2008, 12, pp. 285-313; https://doi.org/10.1017/S1365100507070150.

Card, D. and Lemieux, T. "Can Falling Supply Explain the Rising Return to College for Younger Men? A Cohort-Based Analysis." Quarterly Journal of Economics, 2001, 116, pp. 705-46; https://doi.org/10.1162/00335530151144140.

De Nardi, M. and Fella, G. "Saving and Wealth Inequality." Review of Economic Dynamics, 2017, 26, pp. 280-300; https://doi.org/10.1016/j.red.2017.06.002.

Eika, L.; Mogstad, M. and Zafar, B. "Educational Assortative Mating and Household Income Inequality." Journal of Political Economy (forthcoming).

Emmons, W.R.; Kent, A.H. and Ricketts, L.R. "The Financial Returns from College across Generations: Large but Unequal." Federal Reserve Bank of St. Louis The Demographics of Wealth 2018 Series, 2018, Essay No. 1; https://www.stlouisfed.org/household-financial-stability/the-demographics-of-wealth/the-financial-returns-from-college-across-generations.

Fagereng, A.; Guiso, L.; Malacrino, D. and Pistaferri, L. "Heterogeneity and Persistence in Returns to Wealth." IMF Working paper No. 18/171, 2018; https://doi.org/10.5089/9781484370063.001.

Fortin, N.M. "Higher-Education Policies and the College Wage Premium: Cross-State Evidence from the 1990s." American Economic Review, 2006, 96, pp. 959-87; https://doi.org/10.1257/aer.96.4.959.

Goldin, C. and Katz, L.F. "Long-Run Changes in the Wage Structure: Narrowing, Widening, Polarizing." Brookings Papers on Economic Activity, 2007, 38, pp. 135-68; https://doi.org/10.3386/w13568.

Greenwood, J.; Guner, N.; Kocharkov, G. and Santos, C. "Marry Your Like: Assortative Mating and Income Inequality." American Economic Review: Papers and Proceedings, 2014, 104(5), pp. 348-53; https://doi.org/10.1257/aer.104.5.348.

Greenwood, J.; Guner, N.; Kocharkov, G. and Santos, C. "Corrigendum to Marry Your Like: Assortative Mating and Income Inequality." Correction, June 18, 2015; https://doi.org/10.3386/w19829.

Haveman, R. and Smeeding, T. "The Role of Higher Education in Social Mobility." The Future of Children, 2006, 16, pp. 125-50; https://doi.org/10.1353/foc.2006.0015.

Huggett, M. "The Risk-Free Rate in Heterogeneous-Agent Incomplete-Insurance Economies." Journal of Economic Dynamics and Control, 1993, 17, pp. 953-69; https://doi.org/10.1016/0165-1889(93)90024-M.

Hurst, E. and Lusardi, A. "Liquidity Constraints, Household Wealth, and Entrepreneurship." Journal of Political Economy, 2004, 112, pp. 319-47; https://doi.org/10.1086/381478.

Jordà, Ò.; Schularick, M. and Taylor, A.M. "Macrofinancial History and the New Business Cycle Facts," in M. Eichenbaum and J.A. Parker, eds., NBER Macroeconomics Annual 2016. National Bureau of Economic Research, 2017, 31, pp. 213-63; https://doi.org/10.1086/690241.

Katz, L.F. and Autor, D.H. "Changes in the Wage Structure and Earnings Inequality," in O. Ashenfelter and D. Card, eds., Handbook of Labor Economics. Volume 3. Chap. 26. Elsevier, 1999, pp. 1463-555; https://doi.org/10.1016/S1573-4463(99)03007-2.

Kuhn, M.; Schularick, M. and Steins, U.I. "Wealth and Income Inequality in America, 1949-2016." Journal of Political Economy, forthcoming.

Levy, F. and Murnane, R.J. “U.S. Earnings Levels and Earnings Inequality: A Review of Recent Trends and Proposed Explanations." Journal of Economic Literature, 1992, 30, pp. 1333-81. 
Lusardi, A.; Michaud, P.-C. and Mitchell, O.S. "Optimal Financial Knowledge and Wealth Inequality." Journal of Political Economy, 2017, 125, pp. 431-77; https://doi.org/10.1086/690950.

Lusardi, A. and Mitchell, O.S. "Financial Literacy Around the World: An Overview." Journal of Pension Economics and Finance, 2011, 10, pp. 497-508; https://doi.org/10.1017/S1474747211000448.

Lusardi, A. and Mitchell, O.S. "The Economic Importance of Financial Literacy: Theory and Evidence." Journal of Economic Literature, 2014, 52, pp. 5-44; https://doi.org/10.1257/jel.52.1.5.

Pfeffer, F.T. "Growing Wealth Gaps in Education." Demography, 2018, 55, pp. 1033-68; https://doi.org/10.1007/s13524-018-0666-7.

Pfeffer, F.T. and Killewald, A. "Generations of Advantage. Multigenerational Correlations in Family Wealth." Social Forces, 2018, 96, pp. 1411-42; https://doi.org/10.1093/sf/sox086.

Pfeffer, F.T.; Schoeni, R.F.; Kennickell, A. and Andreski, P. "Measuring Wealth and Wealth Inequality: Comparing Two U.S. Surveys." Journal of Economic and Social Measurement, 2016, 41, pp. 103-20; https://doi.org/10.3233/JEM-160421.

Piketty, T. and Saez, E. "Income Inequality in the United States, 1913-1998." Quarterly Journal of Economics, 2003, 118, pp. 1-39; https://doi.org/10.1162/00335530360535135.

Reeves, R.V. and Howard, K. "The Glass Floor: Education, Downward Mobility, and Opportunity Hoarding." Brookings Research Report, 2013.

Saez, E. and Zucman, G. "Wealth Inequality in the United States since 1913: Evidence from Capitalized Income Tax Data." Quarterly Journal of Economics, 2016, 131, pp. 519-78; https://doi.org/10.1093/qje/qjw004.

Schenker, N. and Taylor, J.M. "Partially Parametric Techniques for Multiple Imputation." Computational Statistics \& Data Analysis, 1996, 22, pp. 425-46; https://doi.org/10.1016/0167-9473(95)00057-7.

Von Gaudecker, H.-M. "How Does Household Portfolio Diversification Vary with Financial Literacy and Financial Advice?" Journal of Finance, 2015, 70, pp. 489-507; https://doi.org/10.1111/jofi.12231. 
